OPEN ACCESS

Edited by:

Nikolay Hristov Mehterov, Plovdiv Medical University, Bulgaria

Reviewed by:

Claudia Cava,

Institute of Bioimaging and

Molecular Physiology

(CNR), Italy

Wenjun Yi,

Central South University, China

*Correspondence:

Dajin Chen

zju2001@zju.edu.cn

Specialty section:

This article was submitted to

Cancer Genetics,

a section of the journal

Frontiers in Oncology

Received: 04 January 2022 Accepted: 01 February 2022

Published: 25 February 2022

Citation:

Yao Q, Zhang X and Chen D

(2022) Emerging Roles and Mechanisms of IncRNA FOXD3-

AS1 in Human Diseases.

Front. Oncol. 12:848296. doi: 10.3389/fonc.2022.848296

\section{Emerging Roles and Mechanisms of IncRNA FOXD3-AS1 in Human Diseases}

\author{
Qinfan Yao ${ }^{1,2,3,4}$, Xiuyuan Zhang ${ }^{1,2,3,4}$ and Dajin Chen ${ }^{1,2,3,4^{*}}$ \\ ${ }^{1}$ Kidney Disease Center, The First Affiliated Hospital, College of Medicine, Zhejiang University, Hangzhou, China, \\ 2 Key Laboratory of Kidney Disease Prevention and Control Technology, Hangzhou, China, ${ }^{3}$ National Key Clinical \\ Department of Kidney Diseases, Institute of Nephrology, Zhejiang University, Hangzhou, China, ${ }^{4}$ Zhejiang Clinical Research \\ Center of Kidney and Urinary System Disease, Hangzhou, China
}

Numerous long noncoding RNAs (IncRNAs) have been identified as powerful regulators of human diseases. The IncRNA FOXD3-AS1 is a novel IncRNA that was recently shown to exert imperative roles in the initialization and progression of several diseases. Emerging studies have shown aberrant expression of FOXD3-AS1 and close correlation with pathophysiological traits of numerous diseases, particularly cancers. More importantly, FOXD3-AS1 was also found to ubiquitously impact a range of biological functions. This study aims to summarize the expression, associated clinicopathological features, major functions and molecular mechanisms of FOXD3-AS1 in human diseases and to explore its possible clinical applications.

Keywords: long noncoding RNA, FOXD3-AS1, clinicopathological feature, function, mechanism

\section{INTRODUCTION}

Based on the in-depth advance of high-throughput sequencing technologies, an emerging number of long non-coding RNAs (lncRNAs) has been identified over recent decades (1-5). LncRNA is a novel type of non-coding RNA molecules with over 200 bp $(6,7)$, accounting for the largest proportion of non-coding RNAs (ncRNA) (8-10). Due to the continuous investigation of lncRNAs, it is believed that lncRNAs are closely related to the occurrence and development of tumors and other diseases (11-15). Several studies have corroborated that lncRNAs are extensively implicated in a range of cellular processes, such as chromatin and genome modifications, transcription activation and interference, nuclear transport (16-20), as well as cell growth, differentiation, and apoptosis. Moreover, lncRNA-based clinical applications have been increasingly explored over the last few years and several mechanisms for such applications have been identified (21-23).

LncRNA forkhead box D3 antisense 1 (FOXD3-AS1), an antisense transcript of the proteincoding gene FOXD3, is a recently discovered lncRNA located in chromosome 1p31.3. Growing evidence reports that FOXD3-AS1 is abnormally expressed in many disease types and its expression seems to be closely associated with significant clinical features. Functional assays demonstrated that FOXD3-AS1 is a crucial regulator in a wide range of biological functions in disease. Therefore, these properties rendered FOXD3-AS1 as a promising biomarker for various applications, including diagnosis, treatment, and prognosis of specific diseases. In this review, we aim to recapitulate the abnormal expression, clinical features, biological roles, corresponding mechanisms, and future clinical applications of FOXD3-AS1 in various human diseases. 


\section{THE ROLE OF IncRNA FOXD3-AS1 IN DISEASES}

Increasing evidence has shown that lncRNA FOXD3-AS1 is abnormally expressed in various human diseases, including lung cancer (24-28), breast cancer $(29,30)$, cervical cancer $(31$, $32)$, nasopharyngeal carcinoma $(33,34)$, osteosarcoma (35), colorectal cancer (36), melanoma (37, 38), liver cancer (39), thyroid cancer (40), neuroblastoma (41), glioma (42), allergic rhinitis (43), retinal infection with Toxoplasma gondii-ocular toxoplasmosis (44), ischemic stroke (45), myocardial ischemia $(46,47)$ and acute respiratory distress syndrome (48). Further studies demonstrated that aberrant expression of FOXD3-AS1 is closely associated to clinicopathological characteristics, such as tumor size, tumor grade, distant lymph node metastasis, differentiation of tumor tissues, overall survival, progressionfree survival, and survival time of patients (Table 1). Moreover, the specific role and related molecular mechanisms of FOXD3AS1 in the occurrence and development of diseases are shown in Table 1.

In the following section, we recapitulated the role of FOXD3AS1 in different disease types, including dysregulated expression, related clinicopathological features and biological functions.

\section{Cancer}

\section{Lung Cancer}

Lung cancer is a major public health problem worldwide, while non-small cell lung cancer (NSCLC) represents about $80-90 \%$ of all cases (49-53). Indeed, NSCLC has a high mortality rate, and the 5-year survival rate of these patients remain challenging (5457). Despite advancements in early detection and treatment of NSCLC, the identification of molecular markers associated with patient survival is still necessary $(53,58-60)$. Multiple studies have demonstrated that FOXD3-AS1 is overexpressed in NSCLC tissues and cell lines (H1299, A549 and SPC-A1 cells) (24, 2628). In addition, FOXD3-AS1 exerts pro-cancer effects in vitro and in vivo by regulating cell proliferation, migration, apoptosis as well as chemo-resistance. Contradictorily, Ji $\mathrm{T}$ et al. first proposed that FOXD3-AS1 was down-regulated in NSCLC tissues and H1299, NCI-H460, A549 and L9981 cell lines, while FOXD3-AS1 levels were inversely correlated with aggressive lymph node metastasis and tumor grade (25). Later, FOXD3-AS1 was confirmed to play an onco-suppressive role by inhibiting cell proliferation and invasion of H1299 and A549 cells. It is worth noting that the contradictory effect of FoxD3AS1 in this study was only assessed in vitro and may be partly due to the remarkably heterogeneous properties of lung cancers. Therefore, further verification of FoxD3-AS1 on animal models of lung cancer is still required (61-65).

\section{Breast Cancer}

Breast cancer has a high incidence and mortality in women (66, 67). Accumulating evidence has suggested that aberrant expression of lncRNAs is implicated in the tumorigenesis of breast cancer (68-71). FoxD3-AS1 expression was found to be significantly upregulated in breast cancer tissues, in addition to T47D, MCF7, BT549, and MDA-MB-231 cells. Interestingly, its overexpression correlated with survival probability, tumor size, and distant metastasis. Moreover, FoxD3-AS1 has been proposed to serve as a novel tumor promoter in the development and progression of breast cancer by enhancing cell proliferation, migration, invasion and tamoxifen (TMX) resistance $(29,30)$.

\section{Cervical Cancer}

Although vaccination against HPV and cervical cancer screening have remarkably reduced cervical cancer incidence and mortality $(30,72,73)$, this cancer is still the most prevalent malignancy in women, with high mortality rate (74-77). Several studies have demonstrated that FOXD3-AS1 is markedly upregulated in cervical cancer tissues and cell lines such as HeLa, SiHa, Caski, SW756, C33A, ME-180, and HT-3 (31, 32). High levels of FOXD3-AS1 were linked to poorly differentiated tumors, large tumors, positive lymph node metastasis, distant metastasis, and worse International Federation of Gynecology and Obstetrics stage. FOXD3-AS1 displayed pro-oncogenic capacity by facilitating cell proliferation, apoptosis, migration and invasion.

\section{Nasopharyngeal Carcinoma}

Nasopharyngeal carcinoma is an endemic carcinoma in Southern China and is often diagnosed at an advanced stage (78-81). Effective markers for its early diagnosis are urgently needed to improve patient survival and reduce mortality rates (82-84). The expression level of FOXD3-AS1 was found to be upregulated in nasopharyngeal carcinoma tissues and cell lines (C666-1 and HK1) and positively associated with tumor node metastasis (TNM) stage and a more invasive pathological classification. FOXD3-AS1 was shown to regulate cell proliferation, apoptosis, invasion, migration, cell stemness and tumor growth in a xenograft model in nude mice $(33,41)$ (Figure 1).

\section{Colorectal Cancer}

Colorectal cancer is the most common cancer in the world, characterized by elevated incidence and mortality rates (85-87). Colon adenocarcinoma (COAD) is the most prevalent pathological subtype of colon cancers, constituting $98 \%$ of all newly diagnosed cases of colon cancers (88-92). Previous evidence has indicated that FOXD3-AS1 is upregulated in COAD tissues as well as in HCT116 and SW1116 cells, while its expression correlates with key clinical features, including: TNM stage, poor tumor differentiation, lymph node metastasis, overall survival and progression-free survival (36). A series of functional experiments in vitro and in vivo have validated the oncogenic property of FOXD3-AS1 in colon cancer through of the regulation of cell proliferation, migration, invasion, and apoptosis. However, Tian $\mathrm{Y}$ et al. has also demonstrated that low expression of FOXD3-AS1 in colon cancer patients is associated with worse overall survival (93). Therefore, more research is needed to clarify the specific role of FOXD3-AS1 in colon cancer.

\section{Melanoma}

Melanoma is a highly aggressive and prevalent tumor, which exhibits a gradual upward trend in both morbidity and mortality rates (94-96). Thus, the identification of early diagnostic 
TABLE 1 | The expression, clinical characteristics, and mechanisms of FOXD3-AS1 in disease.

\begin{tabular}{|c|c|c|c|c|c|c|c|c|}
\hline Disease type & Expression & Role & Clinical characteristics & Cell lines & Human samples & Functions & $\begin{array}{c}\text { Related } \\
\text { mechanisms }\end{array}$ & Refs \\
\hline $\begin{array}{l}\text { non-small cell } \\
\text { lung cancer }\end{array}$ & upregulated & $\begin{array}{l}\text { tumor } \\
\text { promoter }\end{array}$ & / & $\begin{array}{l}\text { A549, } \\
\mathrm{H} 1229 \\
\text { and SPC- } \\
\text { A1 }\end{array}$ & $\begin{array}{l}30 \text { patients from Affiliated } \\
\text { Nanhai Hospital, Southern } \\
\text { Medical University, } \\
40 \text { patients from Hwamei } \\
\text { Hospital, } \\
\text { and } 25 \text { patients from } \\
\text { Peking University } \\
\text { Shenzhen Hospital }\end{array}$ & $\begin{array}{l}\text { cell } \\
\text { proliferation, } \\
\text { apoptosis, } \\
\text { invasion, and } \\
\text { chemo- } \\
\text { resistance }\end{array}$ & $\begin{array}{l}\text { miR-135a-5p, } \\
\text { miR-127-3p, } \\
\text { MED28, } \\
\text { ELAVL1, } \\
\text { PI3K, Akt, } \\
\text { and CDK6 }\end{array}$ & $\begin{array}{l}34733371, \\
32742197 \\
32196603 \\
34605863\end{array}$ \\
\hline $\begin{array}{l}\text { non-small cell } \\
\text { lung cancer }\end{array}$ & downregulated & $\begin{array}{l}\text { tumor } \\
\text { suppressor }\end{array}$ & $\begin{array}{l}\text { lymph node metastasis, and } \\
\text { tumor grade }\end{array}$ & $\begin{array}{l}\mathrm{H} 1299 \text {, } \\
\mathrm{NCl}-\mathrm{H} 460 \text {, } \\
\text { A549, and } \\
\text { L9981 }\end{array}$ & $\begin{array}{l}50 \text { patients from } \\
\text { Shenzhen University } \\
\text { General Hospital }\end{array}$ & $\begin{array}{l}\text { cell } \\
\text { proliferation, } \\
\text { invasion, and } \\
\text { EMT }\end{array}$ & $\begin{array}{l}\text { miR-150, and } \\
\text { SRCIN1 }\end{array}$ & 32924985 \\
\hline breast cancer & upregulated & $\begin{array}{l}\text { tumor } \\
\text { promoter }\end{array}$ & $\begin{array}{l}\text { survival probability, tumor size, } \\
\text { and distant metastasis }\end{array}$ & $\begin{array}{l}\text { MDA-MB- } \\
231 \\
\text { BT549, } \\
\text { T47D and } \\
\text { MCF-7 }\end{array}$ & $\begin{array}{l}19 \text { patients from the First } \\
\text { Affiliated Hospital of } \\
\text { Wenzhou Medical } \\
\text { University }\end{array}$ & $\begin{array}{l}\text { cell } \\
\text { proliferation, } \\
\text { invasion, } \\
\text { migration, and } \\
\text { chemo- } \\
\text { resistance }\end{array}$ & $\begin{array}{l}\text { miR-363, } \\
\text { TFF1, PI3K, } \\
\text { and Akt }\end{array}$ & $\begin{array}{l}34424807 \\
31017311\end{array}$ \\
\hline cervical cancer & upregulated & $\begin{array}{l}\text { tumor } \\
\text { promoter }\end{array}$ & $\begin{array}{l}\text { tumor differentiation, tumor } \\
\text { size, Iymph node metastasis, } \\
\text { distant metastasis, overall } \\
\text { survival rate, and International } \\
\text { Federation of Gynecology and } \\
\text { Obstetrics stage }\end{array}$ & $\begin{array}{l}\text { HeLa, } \\
\text { SiHa, } \\
\text { C33A, } \\
\text { SW756, } \\
\text { ME-180, } \\
\text { Caski, and } \\
\text { HT-3 }\end{array}$ & $\begin{array}{l}60 \text { patients from the } \\
\text { Hengshui People's } \\
\text { Hospital, and } 146 \text { patients } \\
\text { from The First Affiliated } \\
\text { Hospital, Heilongjiang } \\
\text { University of Chinese } \\
\text { Medicine }\end{array}$ & $\begin{array}{l}\text { cell } \\
\text { proliferation, } \\
\text { invasion, } \\
\text { migration, and } \\
\text { apoptosis }\end{array}$ & $\begin{array}{l}\text { miR-128-3p, } \\
\text { miR-296-5p, } \\
\text { LIMK1, SP1, } \\
\text { and HMGA1 }\end{array}$ & $\begin{array}{l}33760158, \\
32959937\end{array}$ \\
\hline $\begin{array}{l}\text { nasopharyngeal } \\
\text { carcinoma }\end{array}$ & upregulated & $\begin{array}{l}\text { tumor } \\
\text { promoter }\end{array}$ & $\begin{array}{l}\text { TNM stage, and pathological } \\
\text { type }\end{array}$ & $\begin{array}{l}\text { C666-1, } \\
\text { and HK-1 }\end{array}$ & $\begin{array}{l}52 \text { patients from the Taihe } \\
\text { Hospital, Hubei University } \\
\text { of Medicine }\end{array}$ & $\begin{array}{l}\text { cell } \\
\text { proliferation, } \\
\text { invasion, } \\
\text { migration, } \\
\text { apoptosis, and } \\
\text { stemness }\end{array}$ & $\begin{array}{l}\text { miR-135a-5p, } \\
\text { microRNA- } \\
\text { 185-3p, and } \\
\text { FOXD3 }\end{array}$ & $\begin{array}{l}33204001 \\
33336076\end{array}$ \\
\hline melanoma & upregulated & $\begin{array}{l}\text { tumor } \\
\text { promoter }\end{array}$ & $\begin{array}{l}\text { lymphatic metastasis, tumor } \\
\text { size, AJCC stage, and overall } \\
\text { survival }\end{array}$ & $\begin{array}{l}\text { A2058, } \\
\text { SK-MEL- } \\
28, \text { SK- } \\
\text { MEL-1, } \\
\text { SK-MEL- } \\
2 \text {, and } \\
\text { A375 }\end{array}$ & $\begin{array}{l}47 \text { patients from Weihai } \\
\text { Central Hospital }\end{array}$ & $\begin{array}{l}\text { cell } \\
\text { proliferation, } \\
\text { invasion, } \\
\text { migration, and } \\
\text { apoptosis }\end{array}$ & $\begin{array}{l}\text { miR-127-3p, } \\
\text { miR-325, } \\
\text { FJX1, and } \\
\text { MAP3K2 }\end{array}$ & $\begin{array}{l}32354225 \\
31541886\end{array}$ \\
\hline $\begin{array}{l}\text { hepatocellular } \\
\text { carcinoma }\end{array}$ & upregulated & $\begin{array}{l}\text { tumor } \\
\text { promoter }\end{array}$ & poor prognosis & $\begin{array}{l}\text { Huh7, } \\
\text { Huh6, and } \\
\text { SK-HEP-1 }\end{array}$ & $\begin{array}{l}68 \text { patients from Affiliated } \\
\text { Hospital of Hebei } \\
\text { University }\end{array}$ & $\begin{array}{l}\text { cell } \\
\text { proliferation, } \\
\text { invasion, and } \\
\text { migration }\end{array}$ & $\begin{array}{l}\text { miR-335, } \\
\text { RICTOR, and } \\
\text { AKT }\end{array}$ & 32191537 \\
\hline thyroid cancer & upregulated & $\begin{array}{l}\text { tumor } \\
\text { promoter }\end{array}$ & / & $\begin{array}{l}\text { FTC-133, } \\
\text { SW579, } \\
\text { TPC-1, } \\
\text { and } \\
8505 \mathrm{C}\end{array}$ & $\begin{array}{l}30 \text { patients from Peking } \\
\text { Union Medical College } \\
\text { Hospital }\end{array}$ & $\begin{array}{l}\text { cell } \\
\text { proliferation, } \\
\text { invasion, and } \\
\text { migration }\end{array}$ & $\begin{array}{l}\text { miR-296-5p, } \\
\text { TGF- } \beta 1 \text {, and } \\
\text { Smads }\end{array}$ & 31678422 \\
\hline neuroblastoma & downregulated & $\begin{array}{l}\text { tumor } \\
\text { suppressor }\end{array}$ & $\begin{array}{l}\text { tumor differentiation, } \\
\text { International Neuroblastoma } \\
\text { Staging System (INSS) stage, } \\
\text { and MYCN amplification }\end{array}$ & $\begin{array}{l}\text { NB-1643, } \\
\text { SK-N-BE } \\
\text { (2), NB- } \\
\text { 1691, } \\
\text { IMR32, }\end{array}$ & / & $\begin{array}{l}\text { cell } \\
\text { proliferation, } \\
\text { invasion, } \\
\text { migration, } \\
\text { differentiation, }\end{array}$ & $\begin{array}{l}\text { CTCF, and } \\
\text { PARP1 }\end{array}$ & 29398485 \\
\hline
\end{tabular}


TABLE 1 | Continued

\begin{tabular}{|c|c|c|c|c|c|c|c|c|}
\hline Disease type & Expression & Role & Clinical characteristics & Cell lines & Human samples & Functions & $\begin{array}{c}\text { Related } \\
\text { mechanisms }\end{array}$ & Refs \\
\hline & & & & $\begin{array}{l}\text { and BE } \\
(2)-C\end{array}$ & & $\begin{array}{l}\text { and chemo- } \\
\text { sensitivity }\end{array}$ & & \\
\hline glioma & upregulated & $\begin{array}{l}\text { tumor } \\
\text { promoter }\end{array}$ & $\begin{array}{l}\text { WHO grade, histologic grade, } \\
\text { poor prognosis, and overall } \\
\text { survival }\end{array}$ & $\begin{array}{l}\text { U87, } \\
\text { A172 and } \\
\text { U251 }\end{array}$ & $\begin{array}{l}44 \text { patients from } \\
\text { Changzheng Hospital } \\
\text { (Shanghai, China) }\end{array}$ & $\begin{array}{l}\text { cell } \\
\text { proliferation, } \\
\text { invasion, and } \\
\text { migration }\end{array}$ & FOXD3 & 27829996 \\
\hline ischemia stroke & upregulated & / & / & $\mathrm{N} 2 \mathrm{a}$ & / & cell apoptosis & $\begin{array}{l}\mathrm{miR}-765, \text { and } \\
\text { BCL2L13 }\end{array}$ & 33068927 \\
\hline $\begin{array}{l}\text { myocardial } \\
\text { disease }\end{array}$ & upregulated & / & / & $\begin{array}{l}\mathrm{H} 9 \mathrm{C} 2 \text {, } \\
\text { and } \mathrm{AC} 16\end{array}$ & / & cell apoptosis & $\begin{array}{l}\mathrm{NF}-\kappa \mathrm{B}, \mathrm{iNOS} \text {, } \\
\text { and COX2 }\end{array}$ & $\begin{array}{l}31632535 \\
, 32973515\end{array}$ \\
\hline $\begin{array}{l}\text { acute } \\
\text { respiratory } \\
\text { distress } \\
\text { syndrome }\end{array}$ & upregulated & / & / & $\begin{array}{l}\text { A549, and } \\
\text { Beas2B }\end{array}$ & O & cell apoptosis & $\begin{array}{l}\text { miR-150, and } \\
\text { p53 }\end{array}$ & 28655711 \\
\hline allergic rhinitis & downregulated & / & / & NECs & $\begin{array}{l}25 \text { patients from The } \\
\text { Second Affiliated Hospital } \\
\text { of Nanchang University }\end{array}$ & $\begin{array}{l}\text { Th2 type } \\
\text { immunoreaction }\end{array}$ & IL-25 & 32671514 \\
\hline $\begin{array}{l}\text { retinal infection } \\
\text { with } \\
\text { Toxoplasma } \\
\text { gondii-ocular } \\
\text { toxoplasmosis }\end{array}$ & downregulated & / & l & $\begin{array}{l}\text { human } \\
\text { retinal } \\
\text { Müller } \\
\text { cells }\end{array}$ & / & / & / & 31547203 \\
\hline
\end{tabular}

biomarkers and therapeutic targets remains urgent $(97,98)$. Increased expression of FOXD3-AS1 has been observed in melanoma tissues and cell lines (A2058, SK-MEL-28, SK-MEL-1, SK-MEL-2, and A375 cells) and positively associated with tumor size, AJCC stage, lymphatic metastasis and overall survival $(37,38)$. Functionally, high levels of FOXD3-AS1 facilitate cell proliferation, invasion and migration and repress cell apoptosis in A375, SKMEL-1 and SK-MEL-2 cells. Moreover, experiments in murine models of xenograft tumor with accelerated tumor growth further validated the pro-oncogenic role of FOXD3-AS1 in melanoma.

\section{Liver Cancer}

Liver cancer is considered the sixth most frequent type of cancer, while hepatocellular carcinoma (HCC) is the most common type of liver cancer, consisting of $75-85 \%$ of all cases according to GLOBOCAN 2018 data $(87,99-101)$. Currently, serum AFP is the

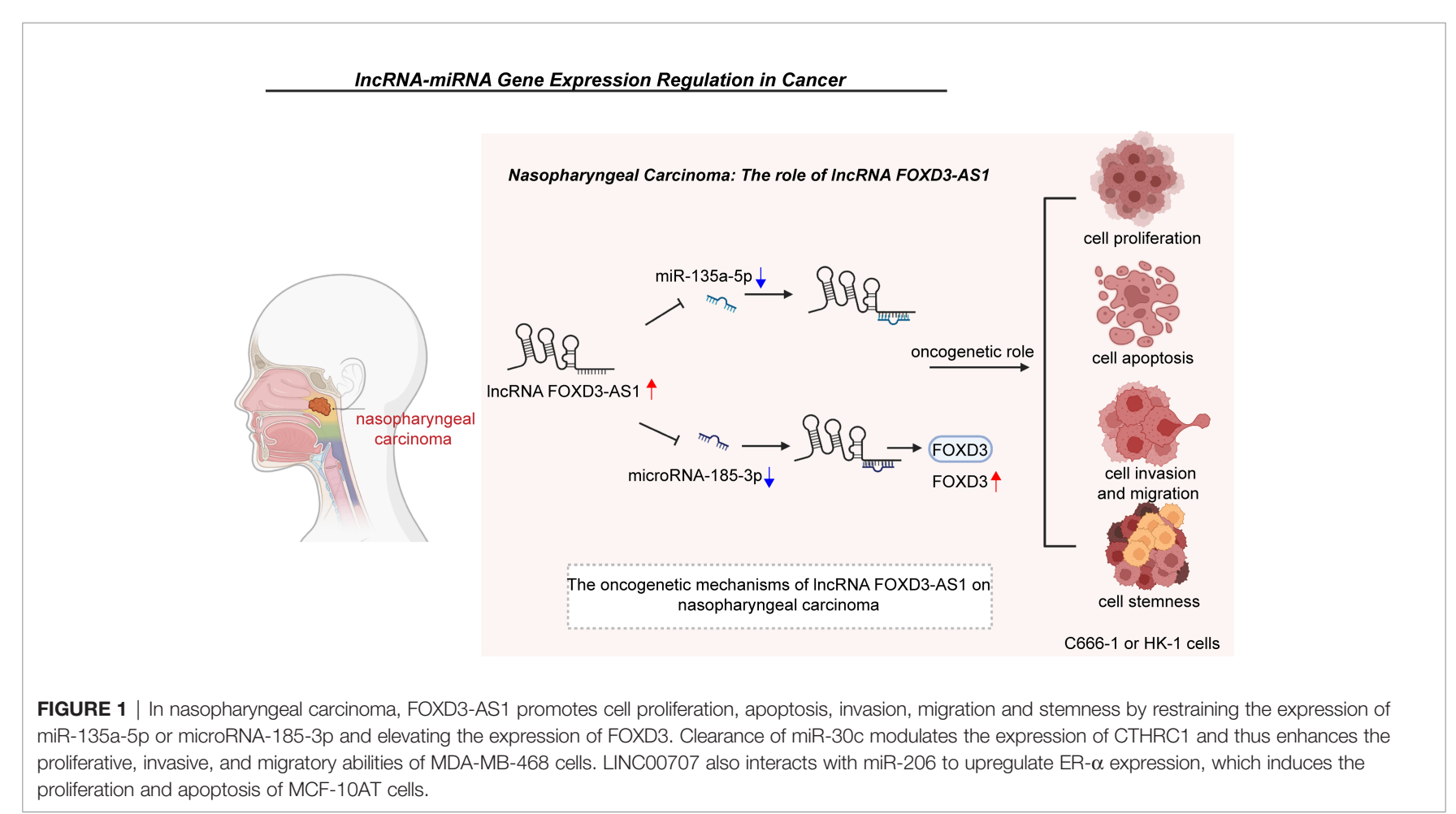


most widely used biomarker for HCC screening, despite its low sensitivity and a high false-negative rate for early HCC diagnosis. Therefore, it is crucial to explore novel biomarkers relevant for the early diagnosis and prognosis of HCC patients $(102,103)$. Indeed, the levels of FOXD3-AS1 have been shown to be significantly decreased in HCC tissues as well as in Huh7, Huh6, and SK-HEP-1 cells compared to health tissues or cells (39). FOXD3-AS1 expression has also been closely associated with poor prognosis of HCC patients. In addition, FOXD3-AS1 has been reported to significantly accelerate malignant processes of cell proliferation, invasion and migration in Huh6 cells, resulting in the development of HCC.

\section{Osteosarcoma}

Osteosarcoma is the most common primary bone tumor in children and young adults (104-108). However, the overall survival of patients with osteosarcoma remains unfavorable despite attempts to improve the efficacy of chemotherapy (109-111). Recent studies have proposed that targeting lncRNAs may provide a novel insight into the treatment of osteosarcoma (112-115). FOXD3-AS1 expression has been found to be upregulated in both osteosarcoma tissues and cell lines (U2OS, MG-63, HOS, SAOS2 and 143B cells) (35). In vitro studies revealed that knockdown of FOXD3-AS1 dramatically impaired the invasion and migration of osteosarcoma cells. In vivo nude mice models have further confirmed that FOXD3-AS1 favors the development and progression of osteosarcoma.

\section{Thyroid Cancer}

It was reported that FOXD3-AS1 was overexpressed in thyroid cancer tissues and FTC-133, SW579, TPC-1, 8505C cells (40). Furthermore, upregulated FOXD3-AS1 expression has been demonstrated to accelerate thyroid tumor growth in in vivo xenograft models and intensify the biological processes of cell proliferation, invasion and migration in FTC-133 cells.

\section{Neuroblastoma}

Neuroblastoma is the most common pediatric malignancy, accounting for $15 \%$ of tumor-related deaths in children (116-119). Although there have been some advancements in the management of neuroblastoma patients, the 5-year eventfree survival rate for high-risk groups is still poor $(120,121)$. Indeed, FOXD3-AS1 was shown to be downregulated in neuroblastoma tissues and NB-1643, SK-N-BE (2), NB-1691, IMR32, and BE (2)-C cells, and was regarded as an independent biomarker for a favorable prognosis (41). Experiments in vitro indicated that FOXD3-AS1 strongly accelerated neuronal differentiation and impaired the proliferation and invasiveness of IMR32 and BE (2)-C cells. Additionally, FOXD3-AS1 expression was inversely correlated with the growth rate of neuroblastoma in an in vivo xenograft model. In this same model, FOXD3-AS1 expression was correlated with a longer survival time of nude mice, corroborating the tumor suppressor roles of FOXD3-AS1 in neuroblastoma.

\section{Glioma}

Previous evidence has shown that FOXD3-AS1 is upregulated in glioma tissues and U87, A172 and U251 cells. Moreover, a higher
FOXD3-AS1 expression was observed in high-grade glioma tissues when compared to that of low-grade glioma tissues (42). FOXD3-AS1 expression has been positively correlated to poorer overall survival and worse tumor grade. More importantly, FOXD3-AS1 has been proposed as an oncogene, favoring the proliferation, invasion and migration of U251 and A172 cells.

\section{Non-Cancer Disease}

\section{Ischemic Stroke}

Ischemic stroke accounts for one of the most impactful diseases worldwide, leading to high mortality and disability rates (122125). Due to the narrow time window and ischemia-reperfusion (I/R) injury, the effect of vascular recanalization and reperfusion treatment has been limited (126-128). Therefore, exploring the exact molecular pathways underlying $I / R$ injury is a pressing concern (129-132). Upon I/R injury, FOXD3-AS1 was found to be overexpressed in vivo and in vitro in oxygen-glucose deprivation/reoxygenation (OGD/R)-induced neuro-2A (N2a) cells (45). Furthermore, FOXD3-AS1 knockdown exerted neuroprotective effects in ischemic stroke by inhibiting neuronal cell apoptosis and cerebral infarction, in addition to facilitating neuronal functional recovery.

\section{Myocardial Disease}

Myocardial ischemia is the major cause of cardiovascular morbidity and mortality in the world (133-135). The pathophysiological process of myocardial $I / R$ injury results in the deficiency of oxygen supply to myocardial cells and subsequent development of oxidative stress, which is vital for energy metabolism, cardiac dysfunction and cell death (136, 137). Therefore, the mitigation of myocardial $I / R$ is needed to improve the quality of life and reduce the mortality of these patients $(138,139)$. High levels of FOXD3-AS1 were found in H9C2 cells subjected to OGD/R during myocardial I/R injury and in hypoxic AC16 cells $(46,47)$. More importantly, FOXD3AS1 has been demonstrated to induce cardiomyocyte autophagy and aggravate the apoptosis of $\mathrm{H} 9 \mathrm{C} 2$ cells, contributing to myocardial I/R injury. Additionally, FOXD3-AS1 knockdown was shown to protect AC16 cardiomyocytes against I/R injury by increasing cell survival and inhibiting apoptosis.

\section{Acute Respiratory Distress Syndrome}

Acute respiratory distress syndrome (ARDS) is a life-threatening clinical condition of acute respiratory failure (140-142). Early diagnosis and prompt initiation of treatment are associated with favorable clinical outcomes in ARDS patients (143-146). Considering that this is a highly heterogeneous syndrome, potential early biological makers are needed to improve the management of ARDS (146-149). Previous reports have shown that FOXD3-AS1 is strikingly overexpressed in lung tissues of an in vivo ARDS model (HALI models) as well as in alveolar epithelial cell line A549, lung bronchial epithelial cells Beas2B and mouse primary lung epithelial cells after exposure to hyperoxia (48). Similar to its role in myocardial hypoxic injury, FOXD3-AS1 was revealed to be involved in the development of oxidative stress upon lung injury by accelerating the apoptosis of A549 and Beas2B cells (Figure 2). 


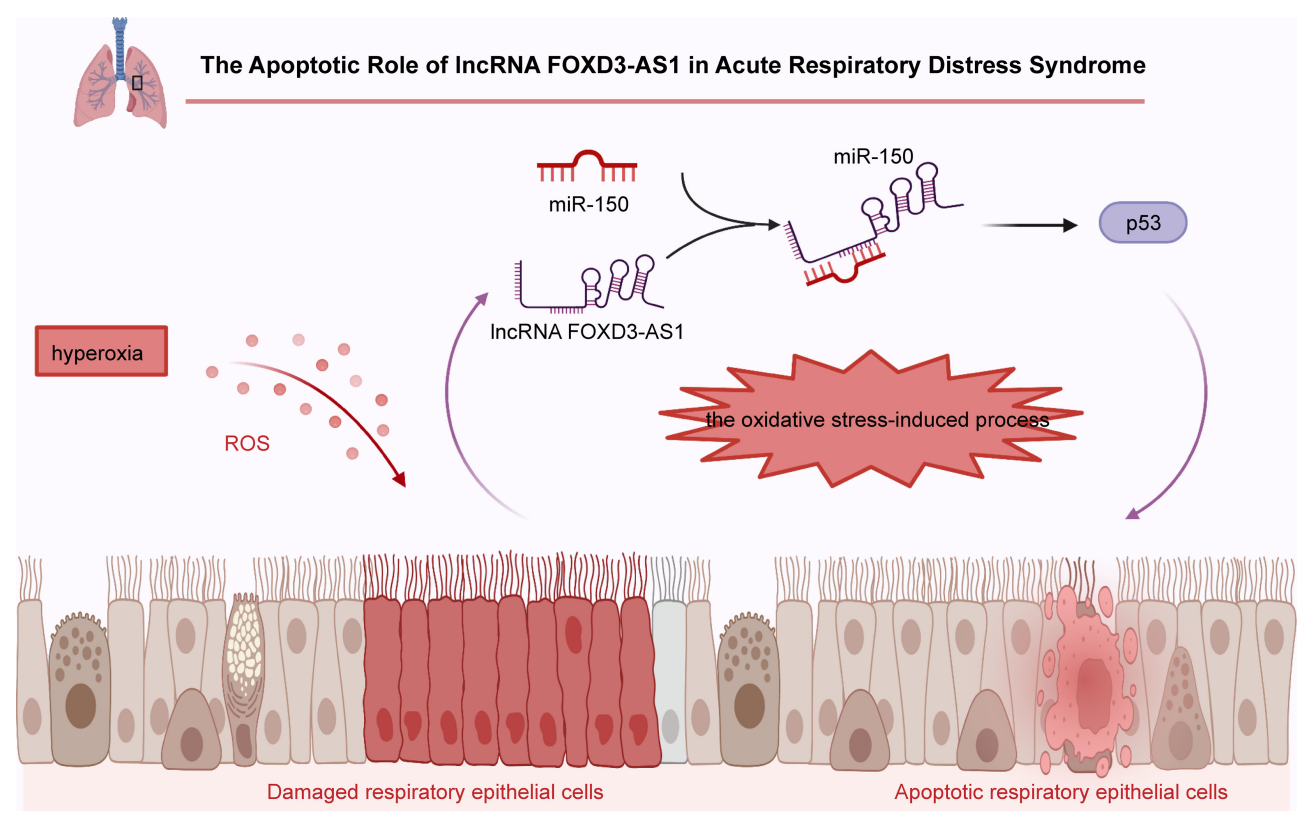

FIGURE 2 | In acute respiratory distress syndrome, FOXD3-AS1 accelerates oxidative stress-induced cell apoptosis by suppressing miR-150 and increasing p53 expression.

\section{Allergic Rhinitis}

Allergic rhinitis (AR) is a common disorder characterized by nasal itching, sneezing and congestion (150-152). A recent study reported that FOXD3-AS1 was severely downregulated in the nasal mucosa of AR patients and nasal epithelial cells (NECs) after LPS treatment (43). Additionally, FOXD3-AS1 was shown to participate in the development of $\mathrm{AR}$ and to protect patients from damage induced by Th2 immunoreaction in AR through the inhibition of IL-25 expression and secretion.

\section{Retinal Infection With Toxoplasma Gondii-Ocular Toxoplasmosis}

Toxoplasmosis is an infection caused by the Toxoplasma gondii parasite and currently available treatments for toxoplasmosis are inefficient (153). A better understanding of the pathogenesis of toxoplasmosis infection is required to develop novel drugs treatments $(154,155)$. FOXD3-AS1 was found to be downregulated in human retinal Müller cells during retinal infection with Toxoplasma gondii-ocular toxoplasmosis. This descriptive in vitro study suggests a role for FOXD3-AS1 in toxoplasmosis infection, however in vivo experiments are still needed (44).

\section{RELEVANT MECHANISMS REGULATED BY FOXD3-AS1}

FOXD3-AS1 has been proved to regulate a range of biological processes, including cell proliferation, apoptosis, invasion, migration, chemoresistance and endoderm differentiation. In the following section, we will recapitulate the main functions and corresponding mechanisms of FOXD3-AS1 in the development and progression of diseases.

\section{Cell Proliferation}

Uncontrolled cell proliferation is the main characteristic of cancers (156-158). FOXD3-AS1 has been demonstrated to promote cell proliferation in NSCLC cells via sponging miR$135 a-5 p$ and further regulating CDK6 level $(27,143)$. FOXD3AS1 was also shown to interact with miR-127-3p and upregulate the expression of MED28. The overexpression of ELAVL1 and activation of the PI3K/Akt pathway was also reported to be a possible pro-proliferative mechanism of FOXD3-AS1 in A549 cells (28). Contrarily, it was found that FOXD3-AS1 suppressed cell proliferation through the miR-150/SRCIN1 axis in A549 and H1229 cells (25). In breast cancer T47D and MCF-7 cells, FOXD3-AS1 cleared the expression of miR-363 and upregulated TFF1 expression and PI3K/Akt signaling, leading to cell proliferation (29). In cervical cancer, FOXD3-AS1 directly interacts with miR-296-5p and elevates HMGA1 levels mediated by transcription factor SP1, thereby enhancing the proliferative ability of HeLa and C33A cells $(31,32)$. In nasopharyngeal carcinoma C666-1 and HK-1 cells, FOXD3-AS1 acts as a promoter of cell proliferation via the inverse regulation of miR-135a-5p (33) or microRNA-185-3p and the upregulation of its downstream gene, FOXD3 (34). In colon adenocarcinoma, FOXD3-AS1 was shown to upregulate SIRT1 by clearing miR135a-5p in HCT116 and SW1116 cells, which is suggestive of increased cell. In melanoma A375, SK-MEL-1 and SK-MEL-2 cells, FOXD3-AS1 facilitates cell proliferation through binding to miR-127-3p and upregulating the expression of FJX1 (37) or by an interaction with miR-325 (38), which then increases the expression of MAP3K2. In hepatocellular carcinoma, FOXD3- 
AS1 improves the expression of RICTOR and activates AKT signaling through an interaction with miR-335, thus exerting a pro-proliferative function in Huh6 cells (39). In thyroid cancer FTC-133 cells, it was confirmed that FOXD3-AS1 promotes cell proliferation by functioning as a miRNA sponge of miR-296-5p and therefore activating the TGF- $\beta 1 / \mathrm{Smads}$ signaling pathway (40). Finally, the specific regulatory mechanism of FOXD3-AS1 in glioma has not been thoroughly studied. It is thought that FOXD3-AS1 may enhance the proliferation of U251 and A172 cells by a partial regulation of FOXD3 expression (42).

\section{Cell Apoptosis}

Apoptosis is a type of programed cell death that has been implicated in the development and occurrence of cancers (159-163). FOXD3-AS1 was demonstrated to suppress the apoptosis of NSCLC A549 and H1229 cells through functioning as a ceRNA for miR-135a-5p and elevating CDK6 expression (24). Similarly, in cervical cancer HeLa and C33A cells, FOXD3-AS1 acts as an oncogene and competitively binds to miR-296-5p, which dramatically increases the levels of HMGA1, thus restraining tumor cells apoptosis (32). FOXD3AS1 was also confirmed to weaken cell apoptosis in nasopharyngeal carcinoma C666-1 and HK-1 cells by negatively regulating miR-135a-5p (33) or microRNA-185-3p and upregulating the level of FOXD3 (34). In colon adenocarcinoma, FOXD3-AS1 was found to protect HCT116 and SW1116 cells from apoptosis via the regulation of miR-135a5p/SIRT1 axis (36). Moreover, it was found that FOXD3-AS1 enhanced cell apoptosis of melanoma A375, SK-MEL-1 and SKMEL-2 cells through either the miR-325/MAP3K2 axis or the miR-127-3p/FJX1 axis $(37,38)$. More importantly, downregulation of FOXD3-AS1 was identified to suppress cell apoptosis and subsequent cerebral I/R injury in ischemic stroke N2a cells through inactivating the expression of miR-765 and facilitating BCL2L13 expression (45). A similar phenomenon has been observed in myocardial I/R injury H9C2 cells, in which FOXD3-AS1 promoted cell autophagy and further exacerbated cell apoptosis through the $\mathrm{NF}-\kappa \mathrm{B} / \mathrm{COX} 2 / \mathrm{iNOS}$ signaling pathway (46). Another reported pro-apoptosis mechanism of FOXD3-AS1 in I/R injury of AC16 cardiomyocytes occurs through the downregulation of miR-150-5p (47). In addition, FOXD3-AS1 negatively modulates miR-150 and upregulates its target p53 during oxidative stress in ARDS Beas2B and A549 cells (48).

\section{Cell Invasion and Migration}

Metastasis is a complex process, in which malignant cells spread from the primary tumor to surrounding organs, forming secondary tumors. Full understanding of mechanisms that regulate metastasis is essential (164).

FOXD3-AS1 was shown to enhance the invasion and migration of NSCLC A549 and H1229 cells by interacting with miR-127-3p and increasing MED28 expression (27). However, in NSCLC A549 and H1229 cells, FOXD3-As1 repressed epithelialmesenchymal transition (EMT) and invasion through the activation of ELAVL1-mediated PI3K/Akt pathway and the miR-150/SRCIN1 axis (28). FOXD3-AS1 was also found to attenuate the invasiveness of neuroblastoma IMR32 and BE (2)-C cells by inhibiting the expression of PARP1 and CTCF (41). In cervical cancer HeLa and C33A cells, FOXD3-AS1 accelerates invasion and migration by competitively binding to miR-128-3p and elevating LIMK1 expression (31) as well as through clearing miR-296-5p and subsequently increasing HMGA1 levels (32). It was also reported in osteosarcoma MG63 and HOS cells that FOXD3-AS1 is able to promote migration and EMT through the activation of ELF1, which is mediated by an interaction with miR-296-5p and increased levels of ZCCHC3 (35). In addition, FOXD3-AS1 antagonizes the expression of miR-135a-5p and upregulates SIRT1 in colon adenocarcinoma HCT116 and SW1116 cells, thus contributing to cell invasion and migration (36). Similarly, in melanoma A375, SK-MEL-1 and SK-MEL-2 cells, FOXD3-AS1 facilitated cell migration via miR-127-3p/FJX1 and/or miR-325/MAP3K2 (37, 38). FOXD3AS1 promotes the invasion and migration of hepatocellular carcinoma Huh6 cells by serving as a miR-335 sponge, enhancing RICTOR expression and activating the AKT signaling pathway (39). In thyroid cancer FTC-133 cells, FOXD3-AS1 positively regulated cell migration and invasion through the inhibition of miR-296-5p and upregulation of the TGF- $\beta 1 /$ Smads signaling pathway (40). Moreover, it was demonstrated that FOXD3-AS1 also promotes invasion and migration of glioma U251 and A172 cells through a partial modulation of FOXD3 (42).

\section{Cell Chemoresistance}

Insensitivity to chemotherapy is a primary cause of treatment failure and shortens the life expectancy of patients $(165,166)$. Therefore, there is an urgent need for thoroughly understanding its mechanisms in order to develop new strategies to prevent drug resistance $(167,168)$.

FOXD3-AS1 was found to promote cisplatin-resistance in NSCLC A549 and H1299 cells via the repression of miR-127-3p and subsequently increase of MDM2 (26). Moreover, FOXD3AS1 has also been proved to intensify 5-fluorouracil resistance in NSCLC A549 cells through increasing ELAVL1 expression and the PI3K/Akt pathway (28). In addition, FOXD3-AS1 has been reported to enhance tamoxifen (TMX) resistance in breast cancer T47D and MCF7 cells through the microRNA-363/TFF1/PI3K/ Akt signaling pathway (29). Notably, FOXD3-AS1 enhances the sensitivity of chemotherapeutic drugs in neuroblastoma IMR32 and BE (2)-C cells through repression of PARP1-mediated PARylation of CTCF (41) (Figure 3).

\section{Cell Stemness and Differentiation}

Accumulating evidence suggests that cells with stem-like characteristics favor tumor development, such as metastasis and chemoresistance (169-172). Further investigation concerning the molecular biology of cancers is expected to promote the development of alternative therapies targeting the properties of cell stemness (173-176). FOXD3-AS1 was implicated in the regulation of stem-like properties of nasopharyngeal carcinoma C666-1 and HK-1 cells by inhibiting miR-185-3p expression and consequently increasing FOXD3 levels (34). FOXD3-AS1 also stimulates differentiation 


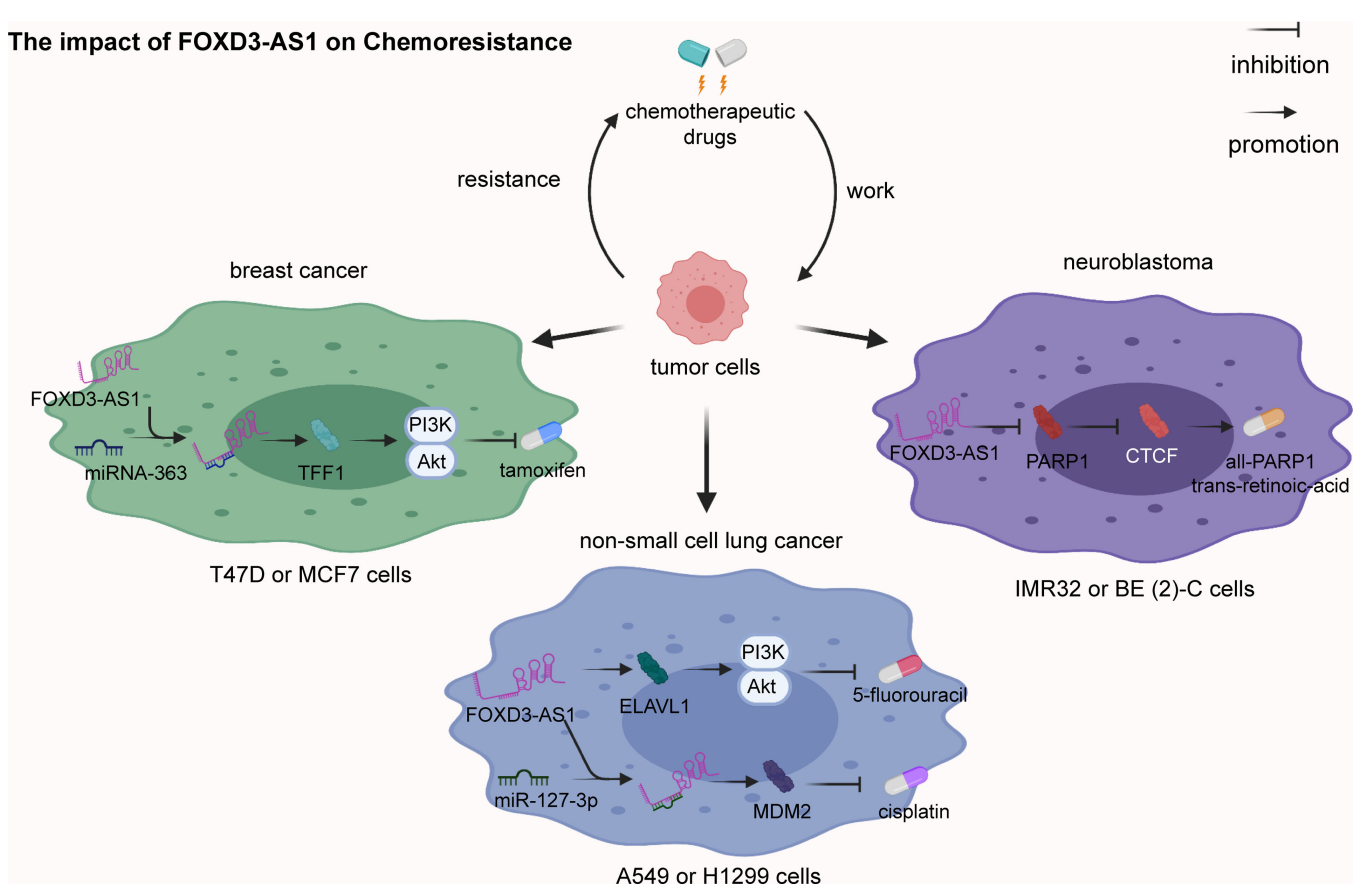

FIGURE 3 | The impact of FOXD3-AS1 on chemoresistance. In non-small cell lung cancer A549 or H1299 cells, FOXD3-AS1 promotes cisplatin-resistance via inhibiting miR-127-3p expression and upregulating MDM2 expression. FOXD3-AS1 also enhances 5-fluorouracil resistance via activating ELAVL1 and the PI3K/Akt pathway. In breast cancer T47D or MCF7 cells, FOXD3-AS1 intensifies tamoxifen (TMX) resistance via clearing microRNA-363 and strengthening TFF1 and the PI3K/AKt signaling pathway. In neuroblastoma IMR32 or BE (2)-C cells, FOXD3-AS1 enhances the sensitivity of all-trans-retinoic-acid (ATRA) via repressing PARP1 and CTCF.

induced by all-trans-retinoic-acid (ATRA) on neuroblastoma IMR32 and BE (2)-C cells through the inhibition of PARP1 and CTCF (41). Additionally, FOXD3-AS1 was first thought to induce pluripotency and differentiation of human embryonic stem cell (hESCs), in which undifferentiated hESCs present a high expression of FOXD3-AS1, while endoderm and mesoderm differentiation is correlated with low FOXD3-AS1 expression (177). Downregulation of FOXD3-AS1 results in pluripotency dysregulation through the inhibition of endoderm pathways.

\section{CLINICAL APPLICATIONS OF FOXD3-AS1}

Based abovementioned mechanisms and effects of FOXD3-AS1, there has been increasing interest in using FOXD3-AS1 as a promising diagnostic or prognostic biomarker as well as therapeutic target for disease management.

\section{FOXD3-AS1 as a Diagnostic Biomarker}

FOXD3-AS1 is abnormally expressed in multitude diseases, including NSCLC (24-28), breast cancer (29, 30), cervical cancer $(31,32)$, nasopharyngeal carcinoma $(33,34)$, osteosarcoma (35), colon adenocarcinoma (36), melanoma (37, 38), hepatocellular carcinoma (39), thyroid cancer (40), neuroblastoma (41), glioma (42), ischemic stroke (45), myocardial ischemia $(46,47)$, acute respiratory distress syndrome (48), allergic rhinitis (43) and retinal infection with toxoplasma gondii-ocular toxoplasmosis (44). Differential expression of FOXD3-AS1 on specific tissues is able to distinguish pathological tissues from adjacent normal ones, suggesting that FOXD3-AS1 can be a promising diagnostic marker for the early diagnosis of diseases. However, monitoring FOXD3-AS1 expression levels in tissues is an invasive and costly process for clinical practice. Detection of FOXD3-AS1 expression in body fluids, such as blood and urine will likely be more convenient for disease diagnosis.

\section{FOXD3-AS1 as a Prognostic Biomarker}

Several studies have reported that FOXD3-AS1 is significantly associated with clinicopathological features, such as tumor size, tumor grade, TNM stage, poor differentiation of tumor tissues, lymph node metastasis, distant metastasis, survival probability, overall survival and progression-free survival. These characteristics indicate that FOXD3-AS1 can serve as a prognostic biomarker for clinical application. For example, high expression of FOXD3-AS1 has been proved to associate with poor International Federation of Gynecology and Obstetrics stage of cervical cancer, indicating that FOXD3-AS1 could be employed as an independent prognostic biomarker for the prediction of overall survival rates in cervical cancer (32). In particular, FOXD3-AS1 levels show a significant association with benign differentiation, International Neuroblastoma Staging System (INSS) stage, and MYCN amplification in neuroblastoma (41). Taken together, these features render FOXD3AS1 the potential to be a reliable candidate for disease prognosis. 


\section{FOXD3-AS1 as a Treatment Target}

With recent advances in the understanding of FOXD3-AS1 in the pathogenesis of diseases, several relevant molecular mechanisms and signaling pathways may be suitable for targeted therapy. Substantial studies have shown that FOXD3AS1 participates in cell proliferation, apoptosis, metastasis, cell stemness and chemoresistance of various human diseases. Especially, the effect of FOXD3-AS1 on drug resistance has received considerable attention.

Emerging studies have indicated that FOXD3-AS1 induces resistance to chemotherapy and subsequently accelerates the development of different types of cancer. For example, FOXD3AS1 enhances the resistance of NSCLC cells to chemotherapeutic drugs cisplatin and 5-fluorouracil $(26,28)$. Moreover, it has also been demonstrated that FOXD3-AS1 was able to enhance breast cancer cells resistance to tamoxifen (29). However, FOXD3-AS1 has also been reported to enhance neuroblastoma cell sensitivity to ATRA (41). Strategies aimed at targeting FOXD3-AS1 and modulating drug resistance are expected to be a new breakthrough in drug development. However, significant challenges remain for the safety and efficacy of FOXD3-AS1targeted agents due to the lack of sufficient clinical data. Therefore, more in-depth basic research into the function and mechanisms of FOXD3-AS1 in diseases is needed.

\section{CONCLUSION}

Numerous studies have shown that FOXD3-AS1 is highly expressed in multiple diseases, including breast cancer, cervical cancer, nasopharyngeal carcinoma, osteosarcoma, colon adenocarcinoma, melanoma, hepatocellular carcinoma, thyroid cancer, glioma, ischemic stroke, congenital heart disease and acute respiratory distress syndrome. In addition, studies have also revealed that FOXD3-AS1 is downregulated in neuroblastoma and allergic rhinitis, suggesting a protective role. Of note, different reports of FOXD3-AS1 in NSCLC show conflicting results on expression, which might be attributed to various factors, such as tumor heterogeneity (178), different study designs and insufficient

\section{REFERENCES}

1. Gibrat JF. A Short Note on Dynamic Programming in a Band. BMC Bioinf (2018) 19:226 doi: 10.1186/s12859-018-2228-9

2. Zeng C, Hamada M. Identifying Sequence Features That Drive Ribosomal Association for IncRNA. BMC Genomics (2018) 19:906. doi: 10.1186/ s12864-018-5275-8

3. Ji Y, Xue Y. Identification and Clinical Validation of 4-lncRNA Signature for Predicting Survival in Head and Neck Squamous Cell Carcinoma. Onco Targets Ther (2020) 13:8395-411. doi: 10.2147/ott.S257200

4. Zampedri C, Martínez-Flores WA, Melendez-Zajgla J. The Use of Zebrafish Xenotransplant Assays to Analyze the Role of lncRNAs in Breast Cancer. Front Oncol (2021) 11:687594. doi: 10.3389/fonc.2021.687594

5. Li G, Liu T, Zhang B, Chen W, Ding Z. Genome-Wide Identification of a Competing Endogenous RNA Network in Cholangiocarcinoma. J Cell Biochem (2019) 120:18995-9003. doi: 10.1002/jcb.29222

6. Tsai MC, Spitale RC, Chang HY. Long Intergenic Noncoding RNAs: New Links in Cancer Progression. Cancer Res (2011) 71:3-7. doi: 10.1158/0008-5472.Can-10-2483 number of tumor samples. The in-depth understanding of the differential expression of FOXD3-AS1 between normal and pathological tissues and cell lines might be expected to enhance the development of novel strategies for disease diagnosis. Further research with additional cell lines and animal models are needed to fully explore these differences. Moreover, the expression levels of FOXD3-AS1 show a close association with clinicopathological features, such as tumor size, grade, poor differentiation, lymph node metastasis, distant metastasis, overall survival and progression-free survival, which might be available for predicting the prognosis of patients. Mechanistic studies have reported that FOXD3-AS1 promotes cell proliferation, apoptosis, invasion, migration, chemotherapeutic resistance, cell stemness and differentiation. Functional studies of FOXD3-AS1 in recent years have broadened our knowledge of its regulatory mechanisms in disease and brought new perspectives on the clinical applications of FOXD3-AS1. Compared with conventional chemotherapy, molecular-targeted FOXD3-AS1 therapy is expected to show greater specificity and lower systemic toxicity. However, these therapies are still in early stages. The lack of support from clinical trials and toxicological experiments remains a major challenge for the applications of FOXD3-AS1. In addition, the stability and levels of FOXD3-AS1 in serum or other accessible biological samples have yet to be validated. Further molecular mechanisms and larger clinical multicenter studies should be conducted.

\section{AUTHOR CONTRIBUTIONS}

DC provide a source of ideas for this review. XZ collected the related paper. QY drafting and reviewed the manuscript. All authors have contributed substantially to original research and approved the submitted version.

\section{FUNDING}

This work was funded by the National Nature Science Foundation (81802085).

7. Wu W, Gao H, Li X, Zhu Y, Peng S, Yu J, et al. LncRNA TPT1-AS1 Promotes Tumorigenesis and Metastasis in Epithelial Ovarian Cancer by Inducing TPT1 Expression. Cancer Sci (2019) 110:1587-98. doi: 10.1111/ cas. 14009

8. Liu F, Shi T, Qi L, Su X, Wang D, Dong J, et al. lncRNA Profile of Apis Mellifera and its Possible Role in Behavioural Transition From Nurses to Foragers. BMC Genomics (2019) 20:393. doi: 10.1186/s12864-019-5664-7

9. Archer K, Broskova Z, Bayoumi AS, Teoh JP, Davila A, Tang Y, et al. Long Non-Coding RNAs as Master Regulators in Cardiovascular Diseases. Int J Mol Sci (2015) 16:23651-67. doi: 10.3390/ijms161023651

10. Borkiewicz L, Kalafut J, Dudziak K, Przybyszewska-Podstawka A, Telejko I. Decoding LncRNAs. Cancers (Basel) (2021) 13:2643. doi: 10.3390/cancers13112643

11. Chen Y, Li Z, Chen X, Zhang S. Long non-Coding RNAs: From Disease Code to Drug Role. Acta Pharm Sin B (2021) 11:340-54. doi: 10.1016/ j.apsb.2020.10.001

12. Sauvageau M, Goff LA, Lodato S, Bonev B, Groff AF, Gerhardinger C, et al. Multiple Knockout Mouse Models Reveal lincRNAs Are Required for Life and Brain Development. Elife (2013) 2:e01749. doi: 10.7554/eLife.01749 
13. Zhang XW, Li QH, Xu ZD, Dou JJ. STAT1-Induced Regulation of IncRNA ZFPM2-AS1 Predicts Poor Prognosis and Contributes to Hepatocellular Carcinoma Progression via the miR-653/GOLM1 Axis. Cell Death Dis (2021) 12:31. doi: 10.1038/s41419-020-03300-4

14. Charles Richard JL, Eichhorn PJA. Platforms for Investigating LncRNA Functions. SLAS Technol (2018) 23:493-506. doi: 10.1177/2472630318780639

15. Xuan P, Sheng N, Zhang T, Liu Y, Guo Y. CNNDLP: A Method Based on Convolutional Autoencoder and Convolutional Neural Network With Adjacent Edge Attention for Predicting lncRNA-Disease Associations. Int J Mol Sci (2019) 20:4260. doi: 10.3390/ijms20174260

16. Quinn JJ, Chang HY. Unique Features of Long non-Coding RNA Biogenesis and Function. Nat Rev Genet (2016) 17:47-62. doi: 10.1038/nrg.2015.10

17. Gan HH, Pasquali S, Schlick T. Exploring the Repertoire of RNA Secondary Motifs Using Graph Theory; Implications for RNA Design. Nucleic Acids Res (2003) 31:2926-43. doi: 10.1093/nar/gkg365

18. Zhao L, Zhao Y, He Y, Li Q, Mao Y. The Functional Pathway Analysis and Clinical Significance of miR-20a and its Related lncRNAs in Breast Cancer. Cell Signal (2018) 51:152-65. doi: 10.1016/j.cellsig.2018.08.004

19. Sui C, Dong Z, Yang C, Zhang M, Dai B, Geng L, et al. LncRNA FOXD2-AS1 as a Competitive Endogenous RNA Against miR-150-5p Reverses Resistance to Sorafenib in Hepatocellular Carcinoma. J Cell Mol Med (2019) 23:602433. doi: $10.1111 / \mathrm{jcmm} .14465$

20. Xia L, Nie D, Wang G, Sun C, Chen G. FER1L4/miR-372/E2F1 Works as a ceRNA System to Regulate the Proliferation and Cell Cycle of Glioma Cells. J Cell Mol Med (2019) 23:3224-33. doi: 10.1111/jcmm.14198

21. Yang Y, Cai Y, Wu G, Chen X, Liu Y, Wang X, et al. Plasma Long nonCoding RNA, CoroMarker, a Novel Biomarker for Diagnosis of Coronary Artery Disease. Clin Sci (Lond) (2015) 129:675-85. doi: 10.1042/cs20150121

22. Lu L, Yu X, Zhang L, Ding X, Pan H, Wen X, et al. The Long Non-Coding RNA RHPN1-AS1 Promotes Uveal Melanoma Progression. Int J Mol Sci (2017) 18:226. doi: 10.3390/ijms 18010226

23. Yuan L, Xu ZY, Ruan SM, Mo S, Qin JJ, Cheng XD. Long Non-Coding RNAs Towards Precision Medicine in Gastric Cancer: Early Diagnosis, Treatment, and Drug Resistance. Mol Cancer (2020) 19:96. doi: 10.1186/s12943-020-01219-0

24. Guo H, Lin S, Gan Z, Xie J, Zhou J, Hu M. IncRNA FOXD3-AS1 Promotes the Progression of Non-Small Cell Lung Cancer by Regulating the miR135a-5p/CDK6 Axis. Oncol Lett (2021) 22:853. doi: 10.3892/ol.2021.13114

25. Ji T, Zhang Y, Wang Z, Hou Z, Gao X, Zhang X. FOXD3-AS1 Suppresses the Progression of Non-Small Cell Lung Cancer by Regulating miR-150/ SRCIN1axis. Cancer Biomark (2020) 29:417-27. doi: 10.3233/cbm-200059

26. Zeng Z, Zhao G, Zhu H, Nie L, He L, Liu J, et al. LncRNA FOXD3-AS1 Promoted Chemo-Resistance of NSCLC Cells via Directly Acting on miR127-3p/MDM2 Axis. Cancer Cell Int (2020) 20:350. doi: 10.1186/s12935020-01402-9

27. Zeng ZL, Zhu HK, He LF, Xu X, Xie A, Zheng EK, et al. Highly Expressed IncRNA FOXD3-AS1 Promotes non-Small Cell Lung Cancer Progression via Regulating miR-127-3p/Mediator Complex Subunit 28 Axis. Eur Rev Med Pharmacol Sci (2020) 24:2525-38. doi: 10.26355/eurrev_202003_20520

28. Mao G, Mu Z, Wu DA. Exosomal lncRNA FOXD3-AS1 Upregulates ELAVL1 Expression and Activates PI3K/Akt Pathway to Enhance Lung Cancer Cell Proliferation, Invasion, and 5-Fluorouracil Resistance. Acta Biochim Biophys Sin (Shanghai) (2021) 53:1484-94. doi: 10.1093/abbs/ gmab129

29. Ren L, Zhou H, Lei L, Zhang Y, Cai H, Wang X. Long non-Coding RNA FOXD3 Antisense RNA 1 Augments Anti-Estrogen Resistance in Breast Cancer Cells Through the microRNA-363/ Trefoil Factor 1/ Phosphatidylinositol 3-Kinase/Protein Kinase B Axis. Bioengineered (2021) 12:5266-78. doi: 10.1080/21655979.2021.1962694

30. Guan Y, Bhandari A, Xia E, Yang F, Xiang J, Wang O. lncRNA FOXD3-AS1 is Associated With Clinical Progression and Regulates Cell Migration and Invasion in Breast Cancer. Cell Biochem Funct (2019) 37:239-44. doi: 10.1002/cbf.3393

31. Yang X, Du H, Bian W, Li Q, Sun H. FOXD3-AS1/miR-128-3p/LIMK1 Axis Regulates Cervical Cancer Progression. Oncol Rep (2021) 45:62. doi: 10.3892/or.2021.8013

32. Ma WG, Shi SM, Chen L, Lou G, Feng XL. SP1-Induced IncRNA FOXD3-AS1 Contributes to Tumorigenesis of Cervical Cancer by Modulating the miR-2965p/HMGA1 Pathway. J Cell Biochem (2021) 122:235-48. doi: 10.1002/jcb.29846
33. Zhang E, Li C, Xiang Y. LncRNA FOXD3-AS1/miR-135a-5p Function in Nasopharyngeal Carcinoma Cells. Open Med (Wars) (2020) 15:1193-201. doi: 10.1515/med-2020-0177

34. Hu J, Pan J, Luo Z, Duan Q, Wang D. Long non-Coding RNA FOXD3-AS1 Silencing Exerts Tumor Suppressive Effects in Nasopharyngeal Carcinoma by Downregulating FOXD3 Expression via microRNA-185-3p Upregulation. Cancer Gene Ther (2021) 28:602-18. doi: 10.1038/s41417-020-00242-z

35. Wang L. ELF1-Activated FOXD3-AS1 Promotes the Migration, Invasion and EMT of Osteosarcoma Cells via Sponging miR-296-5p to Upregulate ZCCHC3. J Bone Oncol (2021) 26:100335. doi: 10.1016/j.jbo.2020.100335

36. Wu Q, Shi M, Meng W, Wang Y, Hui P, Ma J. Long Noncoding RNA FOXD3-AS1 Promotes Colon Adenocarcinoma Progression and Functions as a Competing Endogenous RNA to Regulate SIRT1 by Sponging miR135a-5p. J Cell Physiol (2019) 234:21889-902. doi: 10.1002/jcp.28752

37. Wan N, Yang W, Cheng H, Wang J. FOXD3-AS1 Contributes to the Progression of Melanoma Via miR-127-3p/FJX1 Axis. Cancer Biother Radiopharm (2020) 35:596-604. doi: 10.1089/cbr.2019.3093

38. Chen X, Gao J, Yu Y, Zhao Z, Pan Y. LncRNA FOXD3-AS1 Promotes Proliferation, Invasion and Migration of Cutaneous Malignant Melanoma via Regulating miR-325/Map3k2. BioMed Pharmacother (2019) 120:109438. doi: 10.1016/j.biopha.2019.109438

39. Liu C, Zhang M, Zhao J, Zhu X, Zhu L, Yan M, et al. LncRNA FOXD3-AS1 Mediates AKT Pathway to Promote Growth and Invasion in Hepatocellular Carcinoma Through Regulating RICTOR. Cancer Biother Radiopharm (2020) 35:292-300. doi: 10.1089/cbr.2019.3335

40. Chen Y, Gao H, Li Y. Inhibition of LncRNA FOXD3-AS1 Suppresses the Aggressive Biological Behaviors of Thyroid Cancer via Elevating miR-296$5 \mathrm{p}$ and Inactivating TGF- $\beta 1 /$ Smads Signaling Pathway. Mol Cell Endocrinol (2020) 500:110634. doi: 10.1016/j.mce.2019.110634

41. Zhao X, Li D, Huang D, Song H, Mei H, Fang E, et al. Risk-Associated Long Noncoding RNA FOXD3-AS1 Inhibits Neuroblastoma Progression by Repressing PARP1-Mediated Activation of CTCF. Mol Ther (2018) 26:755-73. doi: 10.1016/j.ymthe.2017.12.017

42. Chen ZH, Hu HK, Zhang CR, Lu CY, Bao Y, Cai Z, et al. Down-Regulation of Long non-Coding RNA FOXD3 Antisense RNA 1 (FOXD3-AS1) Inhibits Cell Proliferation, Migration, and Invasion in Malignant Glioma Cells. Am J Transl Res (2016) 8:4106-19.

43. Zhang $\mathrm{H}$, Zhu X, Liu X, Wang Y, Liu Y. Long non-Coding RNA FOXD3AS1 Regulates the Expression and Secretion of IL-25 in Nasal Epithelial Cells to Inhibit Th2 Type Immunoreaction in Allergic Rhinitis. Mol Cell Biochem (2020) 473:239-46. doi: 10.1007/s11010-020-03825-4

44. Rochet E, Appukuttan B, Ma Y, Ashander LM, Smith JR. Expression of Long Non-Coding RNAs by Human Retinal Müller Glial Cells Infected With Clonal and Exotic Virulent Toxoplasma Gondii. Noncoding RNA (2019) 5:48. doi: 10.3390/ncrna5040048

45. Lu Y, Han Y, He J, Zhou B, Fang P, Li X. LncRNA FOXD3-AS1 Knockdown Protects Against Cerebral Ischemia/Reperfusion Injury via miR-765/BCL2L13 Axis. BioMed Pharmacother (2020) 132:110778. doi: 10.1016/j.biopha.2020.110778

46. Tong G, Wang Y, Xu C, Xu Y, Ye X, Zhou L, et al. Long non-Coding RNA FOXD3-AS1 Aggravates Ischemia/Reperfusion Injury of Cardiomyocytes Through Promoting Autophagy. Am J Transl Res (2019) 11:5634-44.

47. Zheng J, Peng B, Zhang Y, Ai F, Hu X. FOXD3-AS1 Knockdown Suppresses Hypoxia-Induced Cardiomyocyte Injury by Increasing Cell Survival and Inhibiting Apoptosis via Upregulating Cardioprotective Molecule miR-1505p In Vitro. Front Pharmacol (2020) 11:1284. doi: 10.3389/fphar.2020.01284

48. Zhang D, Lee H, Haspel JA, Jin Y. Long Noncoding RNA FOXD3-AS1 Regulates Oxidative Stress-Induced Apoptosis via Sponging microRNA-150. FASEB J (2017) 31:4472-81. doi: 10.1096/fj.201700091R

49. Pan D, Chen J, Feng C, Wu W, Wang Y, Tong J, et al. Preferential Localization of MUC1 Glycoprotein in Exosomes Secreted by Non-Small Cell Lung Carcinoma Cells. Int J Mol Sci (2019) 20:323. doi: 10.3390/ijms20020323

50. Hu X, Yang F, Liao Y, Li L, Zhao G, Zhang L. Docetaxel-Loaded CholesterolPEG Co-Modified Poly (N-Butyl) Cyanoacrylate Nanoparticles for Antitumor Drug Pulmonary Delivery: Preparation, Characterization, and In Vivo Evaluation. Int J Nanomed (2020) 15:5361-76. doi: 10.2147/ijn.S249511

51. Zhang S, Liu F, Hou X, Cao J, Dai X, Yu J, et al. Synthesis of Novel Analogs of Thieno[2,3-D] Pyrimidin-4(3H)-Ones as Selective Inhibitors of Cancer Cell Growth. Biomolecules (2019) 9:631. doi: 10.3390/biom9100631 
52. Torre LA, Siegel RL, Ward EM, Jemal A. Global Cancer Incidence and Mortality Rates and Trends-An Update. Cancer Epidemiol Biomarkers Prev (2016) 25:16-27. doi: 10.1158/1055-9965.Epi-15-0578

53. Xu Z, Wu Z, Xu J, Zhang J, Yu B. Identification of Hub Driving Genes and Regulators of Lung Adenocarcinoma Based on the Gene Co-Expression Network. Biosci Rep (2020) 40:BSR20200295. doi: 10.1042/bsr20200295

54. Xue C, Li G, Lu J, Li L. Crosstalk Between circRNAs and the PI3K/AKT Signaling Pathway in Cancer Progression. Signal Transduct Target Ther (2021) 6:400. doi: 10.1038/s41392-021-00788-w

55. Brody H. Lung Cancer. Nature (2014) 513:S1. doi: 10.1038/513S1a

56. Zhang H, Liu Y, Yan L, Zhang M, Yu X, Du W, et al. Increased Levels of the Long Noncoding RNA, HOXA-AS3, Promote Proliferation of A549 Cells. Cell Death Dis (2018) 9:707. doi: 10.1038/s41419-018-0725-4

57. Sun L, Li J, Li X, Yang X, Zhang S, Wang X, et al. A Combined RNA Signature Predicts Recurrence Risk of Stage I-IIIA Lung Squamous Cell Carcinoma. Front Genet (2021) 12:676464. doi: 10.3389/fgene.2021.676464

58. Kan CFK, Unis GD, Li LZ, Gunn S, Li L, Soyer HP, et al. Circulating Biomarkers for Early Stage Non-Small Cell Lung Carcinoma Detection: Supplementation to Low-Dose Computed Tomography. Front Oncol (2021) 11:555331. doi: 10.3389/fonc.2021.555331

59. Song X, Traub B, Shi J, Kornmann M. Possible Roles of Interleukin-4 and -13 and Their Receptors in Gastric and Colon Cancer. Int J Mol Sci (2021) 22:727. doi: 10.3390/ijms22020727

60. Pak MG, Shin DH, Lee CH, Lee MK. Significance of EpCAM and TROP2 Expression in non-Small Cell Lung Cancer. World J Surg Oncol (2012) 10:53. doi: 10.1186/1477-7819-10-53

61. Ma Q, Wu K, Li H, Li H, Zhu Y, Hu G, et al. ONECUT2 Overexpression Promotes RAS-Driven Lung Adenocarcinoma Progression. Sci Rep (2019) 9:20021. doi: 10.1038/s41598-019-56277-2

62. Malhotra J, Jabbour SK, Aisner J. Current State of Immunotherapy for nonSmall Cell Lung Cancer. Transl Lung Cancer Res (2017) 6:196-211. doi: $10.21037 /$ tlcr.2017.03.01

63. Lee CH, Yang JR, Chen CY, Tsai MH, Hung PF, Chen SJ, et al. Novel STAT3 Inhibitor LDOC1 Targets Phospho-JAK2 for Degradation by Interacting With LNX1 and Regulates the Aggressiveness of Lung Cancer. Cancers (Basel) (2019) 11:63. doi: 10.3390/cancers11010063

64. Lu CS, Lin CW, Chang YH, Chen HY, Chung WC, Lai WY, et al. Antimetabolite Pemetrexed Primes a Favorable Tumor Microenvironment for Immune Checkpoint Blockade Therapy. J Immunother Cancer (2020) 8: e001392. doi: 10.1136/jitc-2020-001392

65. Wu S, Shen G, Mao J, Gao B. CT Radiomics in Predicting EGFR Mutation in Non-Small Cell Lung Cancer: A Single Institutional Study. Front Oncol (2020) 10:542957. doi: 10.3389/fonc.2020.542957

66. Yan M, Ye L, Feng X, Shi R, Sun Z, Li Z, et al. MicroRNA-590-3p Inhibits Invasion and Metastasis in Triple-Negative Breast Cancer by Targeting Slug. Am J Cancer Res (2020) 10:965-74.

67. Liu L, Wu Y, Zhang C, Zhou C, Li Y, Zeng Y, et al. Cancer-Associated Adipocyte-Derived G-CSF Promotes Breast Cancer Malignancy via Stat3 Signaling. J Mol Cell Biol (2020) 12:723-37. doi: 10.1093/jmcb/mjaa016

68. Wang X, Yang D. The Regulation of RNA Metabolism in Hormone Signaling and Breast Cancer. Mol Cell Endocrinol (2021) 529:111221. doi: 10.1016/j.mce.2021.111221

69. Cui D, Ni C. LncRNA Lnc712 Promotes Tumorigenesis in Hepatocellular Carcinoma by Targeting miR-142-3p/Bach-1 Axis. Cancer Manag Res (2020) 12:11285-94. doi: 10.2147/cmar.S254950

70. Han YJ, Boatman SM, Zhang J, Du XC, Yeh AC, Zheng Y, et al. LncRNA BLAT1 is Upregulated in Basal-Like Breast Cancer Through Epigenetic Modifications. Sci Rep (2018) 8:15572. doi: 10.1038/s41598-018-33629-y

71. Gökmen-Polar Y, Vladislav IT, Neelamraju Y, Janga SC, Badve S. Prognostic Impact of HOTAIR Expression is Restricted to ER-Negative Breast Cancers. Sci Rep (2015) 5:8765. doi: 10.1038/srep08765

72. Getachew S, Getachew E, Gizaw M, Ayele W, Addissie A, Kantelhardt EJ. Cervical Cancer Screening Knowledge and Barriers Among Women in Addis Ababa, Ethiopia. PLoS One (2019) 14:e0216522. doi: 10.1371/ journal.pone. 0216522

73. Ren L, Yang S, Cao Q, Tian J. CRNDE Contributes Cervical Cancer Progression by Regulating miR-4262/ZEB1 Axis. Onco Targets Ther (2021) 14:355-66. doi: 10.2147/ott.S263505
74. Chen S, Wang J. HAND2-AS1 Inhibits Invasion and Metastasis of Cervical Cancer Cells via microRNA-330-5p-Mediated LDOC1. Cancer Cell Int (2019) 19:353. doi: 10.1186/s12935-019-1048-y

75. Hou H, Er P, Cheng J, Chen X, Ding X, Wang Y, et al. High Expression of FUNDC1 Predicts Poor Prognostic Outcomes and Is a Promising Target to Improve Chemoradiotherapy Effects in Patients With Cervical Cancer. Cancer Med (2017) 6:1871-81. doi: 10.1002/cam4.1112

76. Xu C, Ma T, Sun H, Li X, Gao S. Markers of Prognosis for Early Stage Cervical Cancer Patients (Stage IB1, IB2) Undergoing Surgical Treatment. Front Oncol (2021) 11:659313. doi: 10.3389/fonc.2021.659313

77. Gong J, Fan H, Deng J, Zhang Q. LncRNA HAND2-AS1 Represses Cervical Cancer Progression by Interaction With Transcription Factor E2F4 at the Promoter of C16orf74. J Cell Mol Med (2020) 24:6015-27. doi: 10.1111/ jcmm.15117

78. Yang SS, Guo JG, Liu JN, Liu ZQ, Chen EN, Chen CY, et al. Effect of Induction Chemotherapy in Nasopharyngeal Carcinoma: An Updated MetaAnalysis. Front Oncol (2020) 10:591205. doi: 10.3389/fonc.2020.591205

79. Xiao Y, Qing J, Li B, Chen L, Nong S, Yang W, et al. TIM-3 Participates in the Invasion and Metastasis of Nasopharyngeal Carcinoma via SMAD7/ SMAD2/SNAIL1 Axis-Mediated Epithelial-Mesenchymal Transition. Onco Targets Ther (2020) 13:1993-2006. doi: 10.2147/ott.S237222

80. Qiu S, Lu J, Zheng W, Xu L, Lin S, Huang C, et al. Advantages of Intensity Modulated Radiotherapy in Recurrent T1-2 Nasopharyngeal Carcinoma: A Retrospective Study. BMC Cancer (2014) 14:797. doi: 10.1186/1471-240714-797

81. Jia-Yuan X, Wei S, Fang-Fang L, Zhi-Jian D, Long-He C, Sen L. miR-375 Inhibits the Proliferation and Invasion of Nasopharyngeal Carcinoma Cells by Suppressing Pdk1. BioMed Res Int (2020) 2020:9704245. doi: 10.1155/ 2020/9704245

82. Li Y, Li X, Yu X, Lin M, Ouyang H, Xie L, et al. Investigating the Value of Arterial Spin Labeling and Intravoxel Incoherent Motion Imaging on Diagnosing Nasopharyngeal Carcinoma in T1 Stage. Cancer Imaging (2020) 20:62. doi: 10.1186/s40644-020-00339-6

83. Li Y, He Q, Wen X, Hong X, Yang X, Tang X, et al. EZH2-DNMT1Mediated Epigenetic Silencing of miR-142-3p Promotes Metastasis Through Targeting ZEB2 in Nasopharyngeal Carcinoma. Cell Death Differ (2019) 26:1089-106. doi: 10.1038/s41418-018-0208-2

84. Zhang J, Jia L, Lin W, Yip YL, Lo KW, Lau VMY, et al. Epstein-Barr VirusEncoded Latent Membrane Protein 1 Upregulates Glucose Transporter 1 Transcription via the Mtorc1/NF-kb Signaling Pathways. J Virol (2017) 91: e02168-16. doi: 10.1128/jvi.02168-16

85. Sun YD, Zhang H, Chen YQ, Wu CX, Zhang JB, Xu HR, et al. HMGB1, the Next Predictor of Transcatheter Arterial Chemoembolization for Liver Metastasis of Colorectal Cancer? Front Oncol (2020) 10:572418. doi: $10.3389 /$ fonc. 2020.572418

86. Gu MJ, Huang QC, Bao CZ, Li YJ, Li XQ, Ye D, et al. Attributable Causes of Colorectal Cancer in China. BMC Cancer (2018) 18:38. doi: 10.1186/s12885017-3968-z

87. Bray F, Ferlay J, Soerjomataram I, Siegel RL, Torre LA, Jemal A. Global Cancer Statistics 2018: GLOBOCAN Estimates of Incidence and Mortality Worldwide for 36 Cancers in 185 Countries. CA Cancer J Clin (2018) 68:394-424. doi: $10.3322 /$ caac. 21492

88. Zheng G, Zhang G, Zhao Y, Zheng Z. Screening of miRNAs as Prognostic Biomarkers for Colon Adenocarcinoma and Biological Function Analysis of Their Target Genes. Front Oncol (2021) 11:560136. doi: 10.3389/fonc.2021.560136

89. Gong YZ, Ruan GT, Liao XW, Wang XK, Liao C, Wang S, et al. Diagnostic and Prognostic Values of Integrin $\alpha$ Subfamily mRNA Expression in Colon Adenocarcinoma. Oncol Rep (2019) 42:923-36. doi: 10.3892/or.2019.7216

90. Thrumurthy SG, Thrumurthy SS, Gilbert CE, Ross P, Haji A. Colorectal Adenocarcinoma: Risks, Prevention and Diagnosis. BMJ (2016) 354:i3590. doi: 10.1136/bmj.i3590

91. Zhao Z, Qin X. MicroRNA-708 Targeting ZNF549 Regulates Colon Adenocarcinoma Development Through PI3K/AKt Pathway. Sci Rep (2020) 10:16729. doi: 10.1038/s41598-020-73929-w

92. Xue W, Li J, Wang F, Han P, Liu Y, Cui B. A Long non-Coding RNA Expression Signature to Predict Survival of Patients With Colon Adenocarcinoma. Oncotarget (2017) 8:101298-308. doi: 10.18632/ oncotarget. 21064 
93. Tian Y, Zhou J, Zou Y, Luo B, Liu Q, Cao X. Upregulated Long Noncoding RNAs LINC02163 and FEZF1-AS1 Exert Oncogenic Roles in Colorectal Cancer. Anticancer Drugs (2021) 32:66-73. doi: 10.1097/cad. 0000000000000975

94. Xiong $\mathrm{H}, \mathrm{Yu} \mathrm{Q}$, Gong $\mathrm{Y}$, Chen W, Tong Y, Wang Y, et al. Yes-Associated Protein (YAP) Promotes Tumorigenesis in Melanoma Cells Through Stimulation of Low-Density Lipoprotein Receptor-Related Protein 1 (Lrp1). Sci Rep (2017) 7:15528. doi: 10.1038/s41598-017-14764-4

95. Sanna A, Harbst K, Johansson I, Christensen G, Lauss M, Mitra S, et al. Tumor Genetic Heterogeneity Analysis of Chronic Sun-Damaged Melanoma. Pigment Cell Melanoma Res (2020) 33:480-9. doi: 10.1111/ pcmr.12851

96. Basurto-Lozada P, Molina-Aguilar C, Castaneda-Garcia C, Vázquez-Cruz ME, Garcia-Salinas OI, Álvarez-Cano A, et al. Acral Lentiginous Melanoma: Basic Facts, Biological Characteristics and Research Perspectives of an Understudied Disease. Pigment Cell Melanoma Res (2021) 34:59-71. doi: $10.1111 / \mathrm{pcmr} .12885$

97. Leucci E, Coe EA, Marine JC, Vance KW. The Emerging Role of Long nonCoding RNAs in Cutaneous Melanoma. Pigment Cell Melanoma Res (2016) 29:619-26. doi: 10.1111/pcmr.12537

98. Ticha I, Hojny J, Michalkova R, Kodet O, Krkavcova E, Hajkova N, et al. A Comprehensive Evaluation of Pathogenic Mutations in Primary Cutaneous Melanomas, Including the Identification of Novel Loss-of-Function Variants. Sci Rep (2019) 9:17050. doi: 10.1038/s41598-019-53636-x

99. Kunadirek P, Chuaypen N, Jenjaroenpun P, Wongsurawat T, Pinjaroen N, Sirichindakul P, et al. Cell-Free DNA Analysis by Whole-Exome Sequencing for Hepatocellular Carcinoma: A Pilot Study in Thailand. Cancers (Basel) (2021) 13:2229. doi: 10.3390/cancers13092229

100. Harris PS, Hansen RM, Gray ME, Massoud OI, McGuire BM, Shoreibah MG. Hepatocellular Carcinoma Surveillance: An Evidence-Based Approach. World J Gastroenterol (2019) 25:1550-9. doi: 10.3748/wjg.v25.i13.1550

101. He D, Zhang X, Zhu X, Maharjan N, Wang Y, Luo P, et al. Identify and Validate the Transcriptomic, Functional Network, and Predictive Validity of FBXL19-AS1 in Hepatocellular Carcinoma. Front Oncol (2020) 10:609601. doi: $10.3389 /$ fonc. 2020.609601

102. Bruix J, Sherman M. Management of Hepatocellular Carcinoma. Hepatology (2005) 42:1208-36. doi: 10.1002/hep.20933

103. Lee WC, Reuben A, Hu X, McGranahan N, Chen R, Jalali A, et al. Multiomics Profiling of Primary Lung Cancers and Distant Metastases Reveals Immunosuppression as a Common Characteristic of Tumor Cells With Metastatic Plasticity. Genome Biol (2020) 21:271. doi: 10.1186/s13059020-02175-0

104. Liu S, Li J, Kang L, Tian Y, Xue Y. Degradation of Long non-Coding RNACIR Decelerates Proliferation, Invasion and Migration, But Promotes Apoptosis of Osteosarcoma Cells. Cancer Cell Int (2019) 19:349. doi: 10.1186/s12935-019-1076-7

105. Martella E, Ferroni C, Guerrini A, Ballestri M, Columbaro M, Santi S, et al. Functionalized Keratin as Nanotechnology-Based Drug Delivery System for the Pharmacological Treatment of Osteosarcoma. Int J Mol Sci (2018) 19:3670. doi: 10.3390/ijms19113670

106. Lindsey BA, Markel JE, Kleinerman ES. Osteosarcoma Overview. Rheumatol Ther (2017) 4:25-43. doi: 10.1007/s40744-016-0050-2

107. Wang JH, Wu XJ, Duan YZ, Li F. Circular RNA_CNST Promotes the Tumorigenesis of Osteosarcoma Cells by Sponging miR-421. Cell Transplant (2020) 29:963689720926147. doi: 10.1177/0963689720926147

108. Oshiro H, Tome Y, Miyake K, Higuchi T, Sugisawa N, Kanaya F, et al. An mTOR and VEGFR Inhibitor Combination Arrests a Doxorubicin Resistant Lung Metastatic Osteosarcoma in a PDOX Mouse Model. Sci Rep (2021) 11:8583. doi: 10.1038/s41598-021-87553-9

109. Yan GN, Lv YF, Guo QN. Advances in Osteosarcoma Stem Cell Research and Opportunities for Novel Therapeutic Targets. Cancer Lett (2016) 370:268-74. doi: 10.1016/j.canlet.2015.11.003

110. Chaiyawat P, Phanphaisarn A, Sirikaew N, Klangjorhor J, Thepbundit V, Teeyakasem P, et al. IMPDH2 and HPRT Expression and a Prognostic Significance in Preoperative and Postoperative Patients With Osteosarcoma. Sci Rep (2021) 11:10887. doi: 10.1038/s41598-021-90456-4

111. Takenaka S, Tamiya H, Wakamatsu T, Nakai S, Imura Y, Outani H, et al. Impact of Surgical Resection and Reasons for Poor Prognosis of Pelvic
Osteosarcoma Based on the Bone Tumor Registry in Japan. Cancers (Basel) (2021) 13:3320. doi: 10.3390/cancers13133320

112. Cheng DD, Li J, Li SJ, Yang QC, Fan CY. CNOT1 Cooperates With LMNA to Aggravate Osteosarcoma Tumorigenesis Through the Hedgehog Signaling Pathway. Mol Oncol (2017) 11:388-404. doi: 10.1002/1878-0261.12043

113. Dai J, Xu L, Hu X, Han G, Jiang H, Sun H, et al. Long Noncoding RNA OIP5AS1 Accelerates CDK14 Expression to Promote Osteosarcoma Tumorigenesis via Targeting miR-223. BioMed Pharmacother (2018) 106:1441-7. doi: 10.1016/j.biopha.2018.07.109

114. Jiang N, Wang X, Xie X, Liao Y, Liu N, Liu J, et al. IncRNA DANCR Promotes Tumor Progression and Cancer Stemness Features in Osteosarcoma by Upregulating AXL via miR-33a-5p Inhibition. Cancer Lett (2017) 405:46-55. doi: 10.1016/j.canlet.2017.06.009

115. Liu G, Wang L, Han H, Li Y, Lu S, Li T, et al. LncRNA ZFAS1 Promotes Growth and Metastasis by Regulating BMI1 and ZEB2 in Osteosarcoma. Am J Cancer Res (2017) 7:1450-62.

116. Cheung NK, Dyer MA. Neuroblastoma: Developmental Biology, Cancer Genomics and Immunotherapy. Nat Rev Cancer (2013) 13:397-411. doi: $10.1038 / \mathrm{nrc} 3526$

117. Maris JM. Recent Advances in Neuroblastoma. N Engl J Med (2010) 362:2202-11. doi: 10.1056/NEJMra0804577

118. Zhang Q, Zhang Q, Jiang X, Ye Y, Liao H, Zhu F, et al. Collaborative ISL1/ GATA3 Interaction in Controlling Neuroblastoma Oncogenic Pathways Overlapping With But Distinct From MYCN. Theranostics (2019) 9:9861000. doi: 10.7150/thno.30199

119. Leichter AL, Sullivan MJ, Eccles MR, Chatterjee A. MicroRNA Expression Patterns and Signalling Pathways in the Development and Progression of Childhood Solid Tumours. Mol Cancer (2017) 16:15. doi: 10.1186/s12943017-0584-0

120. Li Z, Lim SL, Tao Y, Li X, Xie Y, Yang C, et al. PROTAC Bromodomain Inhibitor ARV-825 Displays Anti-Tumor Activity in Neuroblastoma by Repressing Expression of MYCN or C-Myc. Front Oncol (2020) 10:574525. doi: $10.3389 /$ fonc. 2020.574525

121. Almstedt E, Elgendy R, Hekmati N, Rosén E, Wärn C, Olsen TK, et al. Integrative Discovery of Treatments for High-Risk Neuroblastoma. Nat Commun (2020) 11:71. doi: 10.1038/s41467-019-13817-8

122. Yu S, Yu M, He X, Wen L, Bu Z, Feng J. KCNQ1OT1 Promotes Autophagy by Regulating miR-200a/FOXO3/ATG7 Pathway in Cerebral Ischemic Stroke. Aging Cell (2019) 18:e12940. doi: 10.1111/acel.12940

123. Mensah GA, Norrving B, Feigin VL. The Global Burden of Stroke. Neuroepidemiology (2015) 45:143-5. doi: 10.1159/000441082

124. Ozaki T, Nakamura H, Kishima H. Therapeutic Strategy Against Ischemic Stroke With the Concept of Neurovascular Unit. Neurochem Int (2019) 126:246-51. doi: 10.1016/j.neuint.2019.03.022

125. Murray CJL, Lopez AD, Naghavi M, Wang H. Global, Regional, and National Life Expectancy, All-Cause Mortality, and Cause-Specific Mortality for 249 Causes of Death, 1980-2015: A Systematic Analysis for the Global Burden of Disease Study 2015. Lancet (2016) 388:1459-544. doi: 10.1016/s0140-6736 (16)31012-1

126. He Q, Li Z, Meng C, Wu J, Zhao Y, Zhao J. Parkin-Dependent Mitophagy is Required for the Inhibition of ATF4 on NLRP3 Inflammasome Activation in Cerebral Ischemia-Reperfusion Injury in Rats. Cells (2019) 8:897. doi: $10.3390 /$ cells 8080897

127. Rajesh M, Pan H, Mukhopadhyay P, Bátkai S, Osei-Hyiaman D, Haskó G, et al. Cannabinoid-2 Receptor Agonist HU-308 Protects Against Hepatic Ischemia/Reperfusion Injury by Attenuating Oxidative Stress, Inflammatory Response, and Apoptosis. J Leukoc Biol (2007) 82:1382-9. doi: 10.1189/ jlb.0307180

128. Alawieh A, Elvington A, Zhu H, Yu J, Kindy MS, Atkinson C, et al. Modulation of Post-Stroke Degenerative and Regenerative Processes and Subacute Protection by Site-Targeted Inhibition of the Alternative Pathway of Complement. J Neuroinflamm (2015) 12:247. doi: 10.1186/s12974-015-0464-8

129. Wei J, Wu X, Luo P, Yue K, Yu Y, Pu J, et al. Homerla Attenuates Endoplasmic Reticulum Stress-Induced Mitochondrial Stress After Ischemic Reperfusion Injury by Inhibiting the PERK Pathway. Front Cell Neurosci (2019) 13:101. doi: 10.3389/fncel.2019.00101

130. Hankey GJ. Stroke. Lancet (2017) 389:641-54. doi: 10.1016/s0140-6736(16) 30962-x 
131. Tang W, Dong W, Xie P, Cheng P, Bai S, Ren Y, et al. The Effect of PreCondition Cerebella Fastigial Nucleus Electrical Stimulation Within and Beyond the Time Window of Thrombolytic on Ischemic Stroke in the Rats. PLoS One (2015) 10:e0128447. doi: 10.1371/journal.pone.0128447

132. Feigin VL, Forouzanfar MH, Krishnamurthi R, Mensah GA, Connor M, Bennett DA, et al. Global and Regional Burden of Stroke During 1990-2010: Findings From the Global Burden of Disease Study 2010. Lancet (2014) 383:245-54. doi: 10.1016/s0140-6736(13)61953-4

133. Geng T, Song ZY, Xing JX, Wang BX, Dai SP, Xu ZS. Exosome Derived From Coronary Serum of Patients With Myocardial Infarction Promotes Angiogenesis Through the miRNA-143/IGF-IR Pathway. Int J Nanomed (2020) 15:2647-58. doi: 10.2147/ijn.S242908

134. Benjamin EJ, Blaha MJ, Chiuve SE, Cushman M, Das SR, Deo R, et al. Heart Disease and Stroke Statistics-2017 Update: A Report From the American Heart Association. Circulation (2017) 135:e146-603. doi: 10.1161/ cir.0000000000000485

135. Floud S, Blangiardo M, Clark C, de Hoogh K, Babisch W, Houthuijs D, et al. Exposure to Aircraft and Road Traffic Noise and Associations With Heart Disease and Stroke in Six European Countries: A Cross-Sectional Study. Environ Health (2013) 12:89. doi: 10.1186/1476-069x-12-89

136. Das DK, Maulik N. Preconditioning Potentiates Redox Signaling and Converts Death Signal Into Survival Signal. Arch Biochem Biophys (2003) 420:305-11. doi: 10.1016/j.abb.2003.09.023

137. Turoczi T, Jun L, Cordis G, Morris JE, Maulik N, Stevens RG, et al. HFE Mutation and Dietary Iron Content Interact to Increase Ischemia/ Reperfusion Injury of the Heart in Mice. Circ Res (2003) 92:1240-6. doi: 10.1161/01.Res.0000076890.59807.23

138. Li J, Zhou W, Chen W, Wang H, Zhang Y, Yu T. Mechanism of the Hypoxia Inducible Factor 1/Hypoxic Response Element Pathway in Rat Myocardial Ischemia/Diazoxide Post-Conditioning. Mol Med Rep (2020) 21:1527-36. doi: 10.3892/mmr.2020.10966

139. Alexander Y, Osto E, Schmidt-Trucksäss A, Shechter M, Trifunovic D, Duncker DJ, et al. Endothelial Function in Cardiovascular Medicine: A Consensus Paper of the European Society of Cardiology Working Groups on Atherosclerosis and Vascular Biology, Aorta and Peripheral Vascular Diseases, Coronary Pathophysiology and Microcirculation, and Thrombosis. Cardiovasc Res (2021) 117:29-42. doi: 10.1093/cvr/cvaa085

140. Zhang Z. Identification of Three Classes of Acute Respiratory Distress Syndrome Using Latent Class Analysis. PeerJ (2018) 6:e4592. doi: 10.7717/peerj.4592

141. Mansur A, Steinau M, Popov AF, Ghadimi M, Beissbarth T, Bauer M, et al. Impact of Statin Therapy on Mortality in Patients With Sepsis-Associated Acute Respiratory Distress Syndrome (ARDS) Depends on ARDS Severity: A Prospective Observational Cohort Study. BMC Med (2015) 13:128. doi: 10.1186/s12916-015-0368-6

142. Beck G, Yard BA, Schulte J, Oberacker R, van Ackern K, van der Woude FJ, et al. Inhibition of LPS-Induced Chemokine Production in Human Lung Endothelial Cells by Lipid Conjugates Anchored to the Membrane. $\mathrm{Br} \mathrm{J}$ Pharmacol (2002) 135:1665-74. doi: 10.1038/sj.bjp.0704618

143. Han F, Sun R, Ni Y, Hu X, Chen X, Jiang L, et al. Early Initiation of Continuous Renal Replacement Therapy Improves Clinical Outcomes in Patients With Acute Respiratory Distress Syndrome. Am J Med Sci (2015) 349:199-205. doi: 10.1097/maj.0000000000000379

144. Liu J, Dean DA. Gene Transfer of Mrck $\alpha$ Rescues LipopolysaccharideInduced Acute Lung Injury by Restoring Alveolar Capillary Barrier Function. Sci Rep (2021) 11:20862. doi: 10.1038/s41598-021-99897-3

145. Bellani G, Laffey JG, Pham T, Fan E, Brochard L, Esteban A, et al. Epidemiology, Patterns of Care, and Mortality for Patients With Acute Respiratory Distress Syndrome in Intensive Care Units in 50 Countries. JAMA (2016) 315:788-800. doi: 10.1001/jama.2016.0291

146. Matthay MA, McAuley DF, Ware LB. Clinical Trials in Acute Respiratory Distress Syndrome: Challenges and Opportunities. Lancet Respir Med (2017) 5:524-34. doi: 10.1016/s2213-2600(17)30188-1

147. Meyer NJ, Calfee CS. Novel Translational Approaches to the Search for Precision Therapies for Acute Respiratory Distress Syndrome. Lancet Respir Med (2017) 5:512-23. doi: 10.1016/s2213-2600(17)30187-x

148. Pham T, Rubenfeld GD. Fifty Years of Research in ARDS. The Epidemiology of Acute Respiratory Distress Syndrome. A 50th Birthday Review. Am J Respir Crit Care Med (2017) 195:860-70. doi: 10.1164/rccm.201609-1773CP
149. Orbegozo D, Rahmania L, Irazabal M, Mendoza M, Annoni F, De Backer D, et al. Endocan as an Early Biomarker of Severity in Patients With Acute Respiratory Distress Syndrome. Ann Intensive Care (2017) 7:93. doi: 10.1186/s13613-017-0311-4

150. Danella Figo D, De Amicis K, Neiva Santos de Aquino D, Pomiecinski F, Gadermaier G, Briza P, et al. Cashew Tree Pollen: An Unknown Source of IgE-Reactive Molecules. Int J Mol Sci (2019) 20:2397. doi: 10.3390/ ijms 20102397

151. Greiner AN, Hellings PW, Rotiroti G, Scadding GK. Allergic Rhinitis. Lancet (2011) 378:2112-22. doi: 10.1016/s0140-6736(11)60130-x

152. Kim HB, Eckel SP, Kim JH, Gilliland FD. Exhaled NO: Determinants and Clinical Application in Children With Allergic Airway Disease. Allergy Asthma Immunol Res (2016) 8:12-21. doi: 10.4168/aair.2016.8.1.12

153. Jeffers V, Gao H, Checkley LA, Liu Y, Ferdig MT, Sullivan WJJr. Garcinol Inhibits GCN5-Mediated Lysine Acetyltransferase Activity and Prevents Replication of the Parasite Toxoplasma Gondii. Antimicrob Agents Chemother (2016) 60:2164-70. doi: 10.1128/aac.03059-15

154. Węglińska L, Bekier A, Dzitko K, Pacholczyk-Sienicka B, Albrecht $€$, Plech T, et al. 1,3,4-Thiadiazoles Effectively Inhibit Proliferation of Toxoplasma Gondii. Cells (2021) 10:1053. doi: 10.3390/cells10051053

155. Montazeri M, Mikaeili Galeh T, Moosazadeh M, Sarvi S, Dodangeh S, Javidnia J, et al. The Global Serological Prevalence of Toxoplasma Gondii in Felids During the Last Five Decades (1967-2017): A Systematic Review and Meta-Analysis. Parasit Vectors (2020) 13:82. doi: 10.1186/s13071-0203954-1

156. Hanahan D, Weinberg RA. Hallmarks of Cancer: The Next Generation. Cell (2011) 144:646-74. doi: 10.1016/j.cell.2011.02.013

157. Xiao W, Luo J, Jain T, Riggs JW, Tseng HP, Henderson PT, et al. Biodistribution and Pharmacokinetics of a Telodendrimer Micellar Paclitaxel Nanoformulation in a Mouse Xenograft Model of Ovarian Cancer. Int J Nanomed (2012) 7:1587-97. doi: 10.2147/ijn.S29306

158. Häfliger P, Charles RP. The L-Type Amino Acid Transporter LAT1-An Emerging Target in Cancer. Int J Mol Sci (2019) 20:2428. doi: 10.3390/ ijms 20102428

159. Shehata MG, Abu-Serie MM, Abd El-Aziz NM, El-Sohaimy SA. Nutritional, Phytochemical, and In Vitro Anticancer Potential of Sugar Apple (Annona Squamosa) Fruits. Sci Rep (2021) 11:6224. doi: 10.1038/s41598-021-85772-8

160. Go S, Kramer TT, Verhoeven AJ, Oude Elferink RPJ, Chang JC. The Extracellular Lactate-to-Pyruvate Ratio Modulates the Sensitivity to Oxidative Stress-Induced Apoptosis via the Cytosolic NADH/NAD(+) Redox State. Apoptosis (2021) 26:38-51. doi: 10.1007/s10495-020-01648-8

161. Reyland ME. Protein Kinase Cdelta and Apoptosis. Biochem Soc Trans (2007) 35:1001-4. doi: 10.1042/bst0351001

162. Narayanan KB, Ali M, Barclay BJ, Cheng QS, D'Abronzo L, DornetshuberFleiss R, et al. Disruptive Environmental Chemicals and Cellular Mechanisms That Confer Resistance to Cell Death. Carcinogenesis (2015) 36(Suppl 1):S89-110. doi: 10.1093/carcin/bgv032

163. Tu Y, Chen L, Ren N, Li B, Wu Y, Rankin GO, et al. Standardized Saponin Extract From Baiye No.1 Tea (Camellia Sinensis) Flowers Induced S Phase Cell Cycle Arrest and Apoptosis via AKT-MDM2-P53 Signaling Pathway in Ovarian Cancer Cells. Molecules (2020) 25:3515. doi: 10.3390/molecules25153515

164. Fidler IJ. The Pathogenesis of Cancer Metastasis: The 'Seed and Soil' Hypothesis Revisited. Nat Rev Cancer (2003) 3:453-8. doi: 10.1038/nrc1098

165. de la Loza MC, Wellinger RE. A Novel Approach for Organelle-Specific DNA Damage Targeting Reveals Different Susceptibility of Mitochondrial DNA to the Anticancer Drugs Camptothecin and Topotecan. Nucleic Acids Res (2009) 37:e26. doi: 10.1093/nar/gkn1087

166. Fan J, Wei Q, Koay EJ, Liu Y, Ning B, Bernard PW, et al. Chemoresistance Transmission via Exosome-Mediated EphA2 Transfer in Pancreatic Cancer. Theranostics (2018) 8:5986-94. doi: 10.7150/thno.26650

167. Zhang F, Wang H, Yu J, Yao X, Yang S, Li W, et al. LncRNA CRNDE Attenuates Chemoresistance in Gastric Cancer via SRSF6-Regulated Alternative Splicing of PICALM. Mol Cancer (2021) 20:6. doi: 10.1186/ s12943-020-01299-y

168. YiRen H, YingCong Y, Sunwu Y, Keqin L, Xiaochun T, Senrui C, et al. Long Noncoding RNA MALAT1 Regulates Autophagy Associated Chemoresistance via miR-23b-3p Sequestration in Gastric Cancer. Mol Cancer (2017) 16:174. doi: 10.1186/s12943-017-0743-3 
169. Xu S, Yue Y, Zhang S, Zhou C, Cheng X, Xie X, et al. STON2 Negatively Modulates Stem-Like Properties in Ovarian Cancer Cells via DNMT1/ MUC1 Pathway. J Exp Clin Cancer Res (2018) 37:305. doi: 10.1186/ s13046-018-0977-y

170. Liang X, Xu C, Wang W, Li X. The DNMT1/miR-34a Axis Is Involved in the Stemness of Human Osteosarcoma Cells and Derived Stem-Like Cells. Stem Cells Int (2019) 2019:7028901. doi: 10.1155/2019/7028901

171. Jacobsen SE. Defining 'Stemness': Notch and Wnt Join Forces? Nat Immunol (2005) 6:234-6. doi: 10.1038/ni0305-234

172. Wang X, Liang T, Qiu J, Qiu X, Gao B, Gao W, et al. Melatonin Reverses the Loss of Stemness Induced by TNF- $\alpha$ in Human Bone Marrow Mesenchymal Stem Cells Through Upregulation of YAP Expression. Stem Cells Int (2019) 2019:6568394. doi: 10.1155/2019/6568394

173. Abarrategi A, Tornin J, Martinez-Cruzado L, Hamilton A, Martinez-Campos E, Rodrigo JP, et al. Osteosarcoma: Cells-Of-Origin, Cancer Stem Cells, and Targeted Therapies. Stem Cells Int (2016) 2016:3631764. doi: 10.1155/2016/ 3631764

174. Kansara M, Teng MW, Smyth MJ, Thomas DM. Translational Biology of Osteosarcoma. Nat Rev Cancer (2014) 14:722-35. doi: 10.1038/nrc3838

175. Parafioriti A, Bason C, Armiraglio E, Calciano L, Daolio PA, Berardocco M, et al. Ewing's Sarcoma: An Analysis of miRNA Expression Profiles and Target Genes in Paraffin-Embedded Primary Tumor Tissue. Int J Mol Sci (2016) 17:656. doi: 10.3390/ijms17050656

176. De Vito C, Riggi N, Cornaz S, Suvà ML, Baumer K, Provero $\mathrm{P}$, et al. A TARBP2-Dependent miRNA Expression Profile Underlies Cancer Stem Cell
Properties and Provides Candidate Therapeutic Reagents in Ewing Sarcoma. Cancer Cell (2012) 21:807-21. doi: 10.1016/j.ccr.2012.04.023

177. Haswell JR, Mattioli K, Gerhardinger C, Maass PG, Foster DJ, Peinado P, et al. Genome-Wide CRISPR Interference Screen Identifies Long NonCoding RNA Loci Required for Differentiation and Pluripotency. PLoS One (2021) 16:e252848. doi: 10.1371/journal.pone.0252848

178. de Sousa VML, Carvalho L. Heterogeneity in Lung Cancer. Pathobiology (2018) 85:96-107. doi: 10.1159/000487440

Conflict of Interest: The authors declare that the research was conducted in the absence of any commercial or financial relationships that could be construed as a potential conflict of interest.

Publisher's Note: All claims expressed in this article are solely those of the authors and do not necessarily represent those of their affiliated organizations, or those of the publisher, the editors and the reviewers. Any product that may be evaluated in this article, or claim that may be made by its manufacturer, is not guaranteed or endorsed by the publisher.

Copyright (c) 2022 Yao, Zhang and Chen. This is an open-access article distributed under the terms of the Creative Commons Attribution License (CC BY). The use, distribution or reproduction in other forums is permitted, provided the original author(s) and the copyright owner(s) are credited and that the original publication in this journal is cited, in accordance with accepted academic practice. No use, distribution or reproduction is permitted which does not comply with these terms. 